\title{
Hot Spots and Hot Moments of Soil Moisture Explain Fluctuations in Iron and Carbon Cycling in a Humid Tropical Forest Soil
}

\author{
Diego Barcellos ${ }^{1}$, Christine S. O'Connell ${ }^{2}{ }^{(0}$, Whendee Silver ${ }^{2}\left(\mathbb{D}\right.$, Christof Meile $^{3 \oplus}$ and \\ Aaron Thompson 1,*(D) \\ 1 Department of Crop and Soil Sciences, University of Georgia, Athens, GA 30602, USA; \\ diego.barcellos@yahoo.com.br \\ 2 Department of Environmental Science, Policy, and Management, University of California-Berkeley, Berkeley, \\ CA 94720, USA; coconn@berkeley.edu (C.S.O.); wsilver@berkeley.edu (W.S.) \\ 3 Department of Marine Sciences, University of Georgia, Athens, GA 30602, USA; cmeile@uga.edu \\ * Correspondence: aaront@uga.edu; Tel.: +1-706-410-1293
}

Received: 30 September 2018; Accepted: 27 October 2018; Published: 1 November 2018

\begin{abstract}
Soils from humid forests undergo spatial and temporal variations in moisture and oxygen $\left(\mathrm{O}_{2}\right)$ in response to rainfall, and induce changes in iron $(\mathrm{Fe})$ and carbon $(\mathrm{C})$ biogeochemistry. We hypothesized that high rainfall periods stimulate Fe and $C$ cycling, with the greatest effects in areas of high soil moisture. To test this, we measured Fe and $\mathrm{C}$ cycling across three catenas at valley, slope, and ridge positions every two days for a two-month period in a rainforest in Puerto Rico. Over 12 days without rain, soil moisture, $\mathrm{Fe}^{\mathrm{II}}$, rapidly reducible $\mathrm{Fe}$ oxides $\left(\mathrm{Fe}^{\mathrm{III}}{ }_{\mathrm{RR}}\right)$, and dissolved organic $\mathrm{C}$ (DOC) declined, but Eh and $\mathrm{O}_{2}$ increased; conversely, during a 10-day period of intense rain $(290 \mathrm{~mm})$, we observed the opposite trends. Mixed-effects models suggest precipitation predicted soil moisture, soil redox potential (Eh), and $\mathrm{O}_{2}$, which in turn influenced Fe reduction/oxidation, $\mathrm{C}$ dissolution, and mineralization processes. The approximate turnover time for $\mathrm{HCl}$-extractable $\mathrm{Fe}^{\mathrm{II}}$ was four days for both production and consumption, and may be driven by fluctuations in $\mathrm{Fe}^{\mathrm{III}} \mathrm{RR}_{\mathrm{R}}$ which ranged from $42 \%$ to $100 \%$ of citrate-ascorbate-extractable $\mathrm{Fe}^{\mathrm{III}}$ (short-range order (SRO)-Fe ${ }^{\mathrm{III}}$ ) at a given site. Our results demonstrated that periods of high precipitation (hot moments) influenced Fe and C-cycling within day-to-week timescales, and were more pronounced in humid valleys (hot spots).
\end{abstract}

Keywords: iron reduction; dissolved organic carbon; soil moisture; redox processes

\section{Introduction}

Rainfall infiltrates into the soil, changing soil moisture and oxygen $\left(\mathrm{O}_{2}\right)$ concentrations, and substantially modifying the soil biogeochemical processes that govern carbon $(\mathrm{C})$ and iron (Fe) cycling. These processes have important implications for land management and the soil's response to a changing climate [1-4]. In humid tropical regions, rainfall can be very high, with annual averages ranging from $3 \mathrm{~m}$ to $10 \mathrm{~m}$ (e.g., the Caribbean and Amazon forests) [5-7]. High rainfall accelerates soil genesis by rapidly removing reaction products and maintaining a moist environment for microbial activity, which ultimately results in the accumulation of Fe and Al oxides at the expense of other minerals [8,9]. Rainfall patterns directly influence soil moisture content [10], which can govern C and nutrient biogeochemical cycling and mineral-organic associations and, together with $\mathrm{pH}$, modulate the net primary productivity (NPP) of ecosystems [1].

Variations in soil moisture can lead to changes in $\mathrm{O}_{2}$ concentrations across the landscape [11], influencing elements sensitive to reduction/oxidation (i.e., redox) reactions, such as nitrogen, manganese, iron, sulfur, and carbon [12,13]. Iron oxyhydroxides are particularly important in soils 
from humid tropical regions, as Fe often becomes the most utilized terminal electron acceptor when $\mathrm{O}_{2}$ is depleted, and the reductive dissolution of Fe minerals can release sorbed nutrients and C [14-16]. With enough labile $\mathrm{C}$ and active microorganisms, fluctuating soil moisture and $\mathrm{O}_{2}$ can generate pockets of anoxic conditions, even in well-drained upland soils, creating "slope wetlands" [17]. Changes in soil redox status can stimulate Fe cycling by repeatedly forming low-crystallinity or short-range order (SRO) $\mathrm{Fe}^{\mathrm{III}}$ phases, some of which-below referred to as $\mathrm{Fe}^{\mathrm{III}}{ }_{\mathrm{RR}}$ - are rapidly reducible by microorganisms during anaerobic conditions [18]. Other portions of the SRO Fe ${ }^{\mathrm{III}}$ pool, along with more crystalline $\mathrm{Fe}^{\mathrm{III}}$ phases, such as hematite or well-crystalline goethite, supply electron-accepting capacity over longer timescales $[19,20]$. Thus, assessing shifts in the pools of reduced $\left(\mathrm{Fe}^{\mathrm{II}}\right)$ and rapidly-reducible $\left(\mathrm{Fe}^{\mathrm{III}}{ }_{\mathrm{RR}}\right)$ iron phases are important for predicting soil biogeochemical processes that intersect with Fe cycling.

Soils experiencing spatial and temporal variation in moisture and $\mathrm{O}_{2}$ content may exhibit different rates of Fe reduction, and thus the dissolution of solid-phase C. Carbon is often bound to Fe phases and can be released as dissolved organic carbon (DOC), which then may stimulate microbial respiration and emissions of $\mathrm{CO}_{2}$ and $\mathrm{CH}_{4}$ [21-26]. In addition, during the oxidation of $\mathrm{Fe}^{2+}{ }_{(\mathrm{aq})}$, Fenton reactions can produce $\mathrm{OH}$ radicals and drive additional DOC loss or $\mathrm{CO}_{2}$ production [27-29]. The oxidation of $\mathrm{Fe}^{\mathrm{II}}$ can also facilitate the formation of $\mathrm{Fe}^{\mathrm{III}}$ phases that can co-precipitate with DOC or serve as sorbents for DOC [30]. Soil organic matter is often associated with Fe minerals in humid tropical ecosystems [31-34], and these mineral-organic associations can account for up to $80 \%$ of the total C stocks in mineral soils with low particulate organic matter [35].

Much of our understanding of the coupling of $\mathrm{Fe}-\mathrm{C}$ biogeochemical processes derives from laboratory incubation studies; in contrast, detailed field measurements of short-term (days-weeks) shifts in Fe dynamics are lacking. The rapid fluctuations in soil moisture and $\mathrm{O}_{2}$ content [36] can create hot moments of anoxic soil microsites that facilitate Fe reduction and C decomposition [37]. However, the repeated soil sampling that is necessary to identify this phenomenon in the field is rarely conducted. Spatially, topographic positions (i.e., ridges, slopes, and valleys) often exhibit distinct hydrological and geomorphological characteristics that respond differently to water drainage or accumulation [38], leading to distinct hot spots throughout the landscape. For example, soils from the Luquillo Experimental Forest (LEF) in Puerto Rico exhibited $\mathrm{Fe}^{\mathrm{II}}$ concentrations varying from $22 \mathrm{mmol}$ to $212 \mathrm{mmol}$ of $\mathrm{Fe}^{\mathrm{II}}$ per kg of dry soil over different landscape positions and along an elevation gradient [35]. Thus, redox processes likely proliferate in hot spots, and at specific hot moments across the landscape where and when biogeochemical reaction rates are more rapid [39-41].

We aimed to capture hot moments (of hours to days) of Fe reduction associated with $\mathrm{C}$ decomposition and redox processes across different topographic positions (ridge, slopes, valleys) that could serve as hot spots in the landscape. We hypothesized the following. (1) Rainfall events will alter soil moisture and $\mathrm{O}_{2}$ within hours to days, increasing Fe reduction rates, organic $\mathrm{C}$ mineralization, and DOC release, with rapid changes in redox potential (constituting hot moments). (2) These hot moments will occur more rapidly and persist longer in valley topographic positions (hot spots) and will lead to greater rates of Fe redox transformations associated with $\mathrm{C}$ cycling. We also sought to assess the $\mathrm{HCl}$-extractable $\mathrm{Fe}^{\mathrm{II}}$ turnover times in these humid tropical forest soils. To test these hypotheses, we collected triplicated soil samples over a two-month period from three topographic positions (valley, slope, and ridge) every two to three days from three replicated catenas in a montane forest in Puerto Rico (USA). Measurements included bulk soil extractions of $\mathrm{Fe}^{\mathrm{II}}$, DOC, $\mathrm{pH}$, gravimetric water content, and soil incubations to measure the potential for Fe reduction and the availability of rapidly reducible $\mathrm{Fe}^{\mathrm{III}}$ oxides. In addition, we monitored soil redox potential (Eh), soil $\mathrm{O}_{2}$, volumetric water content, and $\mathrm{CO}_{2}$ and $\mathrm{CH}_{4}$ fluxes. Relationships among these measurements were then analyzed using multivariate statistical techniques (repeated measures). 


\section{Materials and Methods}

\subsection{Site Description, Experimental Design, and Soil Sampling Procedure}

We sampled soils from three topographic positions (ridge, slope, and valley) across three replicated catenas (Figure S1) from May to June of 2016 near the El Verde Field Station (University of Puerto Rico, Río Piedras) (Figure S2) in the Luquillo Experimental Forest (LEF). The studied sites are in the Espíritu Santo watershed, part of the NSF-sponsored Luquillo Critical Zone Observatory (LCZO) and Long-Term Ecological Research (LTER) programs. The parent material is predominantly volcanoclastic rocks derived from Cretaceous andesitic magma [42,43]. Mean annual precipitation is $\sim 3500 \mathrm{~mm} \mathrm{y}^{-1}$ varying from $2600 \mathrm{y}^{-1}$ to $5800 \mathrm{~mm} \mathrm{y}^{-1}$, and characterized by low seasonality, but including extreme rainfall events (as high as $100 \mathrm{~mm} \mathrm{~d}^{-1}$ ) associated with Caribbean storm systems [44]. The dominant tree species in this part of the LEF is the Tabonuco (Dacryodes excelsa).

The catenas form steep and convex-concave hillslopes draining to ephemeral streams that are characterized by heterogeneous soil distribution and microsites across ridges, slopes, and valleys [45]. Catena- 1 is relatively small, with about $5 \mathrm{~m}$ of vertical rise, a steep slope, a gentle ridge, and valley usually characterized by high soil moisture-Global Positioning System (GPS) coordinates in Table S1). Catena-2 is in another hillslope, about $80 \mathrm{~m}$ apart from Catena-1, with $20 \mathrm{~m}$ of vertical rise, containing a spine ridge, a steep and long slope, and a valley that is occasionally flooded with water. Catena- 3 is downstream of Catena-1, in the same hillslope, with a vertical rise of $10 \mathrm{~m}$, a steep slope, a gentle ridge, and thus similar to Catena- 1 except that the valley in Catena- 3 is not as saturated as Catena-1. Catena- 1 was previously studied by O'Connell, Ruan and Silver [36] and Catena-3 was studied by Almaraz [46]. The hillslope hydrology is characterized by valleys constantly receiving water and sediments from upper slope and ridge positions via runoff or lateral movement of water within the soil. Typically, the soils in the Tabonuco forest are Ultisols (Typic Haplohumults) in stable ridges, Oxisols (Inceptic and Aquic Hapludox) in the slopes, and predominately Inceptisols (Typic Eutrudepts) in the valleys [35].

We studied a total of nine sites, with three located on ridges, slopes, and in valleys, respectively. For each sampling site, we allocated three replicate plots of $1.5 \mathrm{~m} \times 1.5 \mathrm{~m}$ for soil sampling (Figure S1). Triplicate composite soil samples from each site were taken within plots for chemical characterization. We sampled soils from the top $15 \mathrm{~cm}$, using a 1-cm diameter soil probe, and each soil sample was taken at least $20 \mathrm{~cm}$ apart from the previous sampling spots (Figure S1). Soil samples were placed in polypropylene bags within a cooler, and analysis (described below) began at the El Verde Field Station within $20 \mathrm{~min}$ of sampling. Samples were taken every two to three days, except when a lack of power in the field station prevented sample processing (for example, from 6 May 2016 to 14 May 2016). We collected soil samples a total of 17 times during the experimental time span of $44 \mathrm{~d}$. The rainfall dataset was acquired from the rainfall gauge collected daily at the El Verde Field Station, which is available on the website of the Luquillo Long-Term Ecological Research Program (https: / /luq.lter.network/data). Collection procedures are described in McDowell and Estrada-Pinto [47].

\subsection{Soil Biogeochemical Characterization and Extractions (Measurements within Days)}

We conducted a series of bulk biogeochemical characterization tests from the triplicated samples including: measurements of $\mathrm{HCl}$-extractable ferrous iron $\left(\mathrm{Fe}^{\mathrm{II}}\right)$, water-extractable dissolved organic carbon $(\mathrm{DOC}), \mathrm{pH}$, and gravimetric water content $\left(\theta_{\mathrm{G}}\right)$; an assessment of rapidly-reducible Fe oxides (abbreviated as $\mathrm{Fe}^{\mathrm{III}} \mathrm{RR}$ ); and on select random samples from the archive, we made general soil characterizations (including Fe and C pools, and soil texture).

Ferrous iron $\left(\mathrm{Fe}^{\mathrm{II}}\right)$ was determined by extraction with $0.5 \mathrm{M}$ of $\mathrm{HCl}$ at a 1:10 soil:solution ratio (50 mg of soil), by shaking for two hours (horizontal shaker), and centrifuging for $10 \mathrm{~min}$ at 11,000 Relative Centrifugal Force (RCF) [48]. The supernatant was taken, and Fe ${ }^{\mathrm{II}}$ was analyzed by the colorimetric ferrozine method, according to Barcellos, et al. [49] and Thompson, et al. [50] with the 562-nm and 500-nm intensities measured in 96-well microplates [51] using a portable Tecan Infinite F50 plate reader. 
Water-extractable dissolved organic carbon (DOC) was obtained by extraction at 1:5 soil:deionized (DI) water ratio (2 $\mathrm{g}$ of soil) and shaking for $1 \mathrm{~h}$ in a horizontal shaker at room temperature [52-54]. The suspension was centrifuged for $15 \mathrm{~min}$ at $4600 \mathrm{RCF}$, and the supernatant was filtrated with $0.70-\mu \mathrm{m}$ glass fiber filters [55]. Filtered supernatants were immediately frozen at $-20^{\circ} \mathrm{C}$ and then shipped to the University of Georgia at the end of the field session and analyzed on a Shimadzu 5050 TOC analyzer.

Soil $\mathrm{pH}$ was measured in 1:1 soil:DI-water ratio (5 g of soil) using an Orion Ross sure-flow $\mathrm{pH}$ electrode. Gravimetric water content $\left(\theta_{\mathrm{G}}\right)$ was determined by oven-drying soils for $>24 \mathrm{~h}$ and reporting the as dry-weight basis. Composite samples selected from random days of sampling (over 10 samples) were pooled (100 $\mathrm{g}$ of soil) and analyzed in triplicate for the following: total elemental analysis by lithium borate fusion prior to acid dissolution followed by ICP-MS analysis, short-range order (SRO) Fe by $0.2 \mathrm{M}$ of sodium citrate/0.05 M of ascorbic acid extraction followed by ICP-MS analysis, total carbon and nitrogen measured in a CHN Carlo Erba Elemental Analyzer, and soil texture determined by a Beckman Coulter LS 13320 Laser diffraction Particle Size Analyzer [56]. Soils were not sampled for catena-3 on 13 June 2016. We additionally archived soil samples from each sampling time-point and site, and stored $\sim 15 \mathrm{~g}$ soil (frozen at $-20^{\circ} \mathrm{C}$ ) for future analysis.

\section{Rapidly-Reducible Fe Oxides ( $\mathrm{Fe}^{\mathrm{III}}{ }_{\mathrm{RR}}$ ) Microbial Bioreduction Assay}

We quantified the amount of rapidly-reducible ferric iron ( $\left.\mathrm{Fe}^{\mathrm{III}} \mathrm{RR}\right)$ using microbial bioreduction assays adapted from Ginn, Meile, Wilmoth, Tang and Thompson [18] to work at the field station using the field-moist fresh soils. Microbial bioreduction assays have been used in other studies to assess the soil's potential for Fe reduction [18,57-59]. We conducted two different assays. In the first, a Shewanella oneidensis MR-1 culture along with a growth medium [18] (see below) was added to the soil (abbreviated as Shewa-Fe ${ }^{\mathrm{III}} \mathrm{RR}$ ), while in the second, the native soil was incubated with growth media only (abbreviated as Media-Fe ${ }^{\mathrm{III}}{ }_{R R}$ ). This assessed the availability of the soil $\mathrm{Fe}^{\mathrm{III}}$ phases for $\mathrm{Fe}$ reduction by the indigenous microbial communities when appropriate nutrients and $\mathrm{C}$ were provided, while the addition of the Fe-reducer Shewanella sp. aimed at overcoming microbial limitations.

For the Shewa-Fe ${ }^{\mathrm{III}} \mathrm{RR}$ treatment, Shewanella oneidensis MR-1 was grown to the late exponential and early stationary phase in a selective media containing $0.5 \mathrm{~g} \mathrm{~L}^{-1}$ of $\mathrm{KH}_{2} \mathrm{PO}_{4}, 1.0 \mathrm{~g} \mathrm{~L}^{-1}$ of $\mathrm{NaSO}_{4}$, $2.0 \mathrm{~g} \mathrm{~L}^{-1}$ of $\mathrm{NH}_{4} \mathrm{Cl}, 1.0 \mathrm{~g} \mathrm{~L}^{-1}$ of yeast extract, $0.5 \mathrm{mM} \mathrm{CaCl}_{2}, 0.1 \mathrm{mM}$ of $\mathrm{MgSO}_{4}, 10 \mathrm{mM}$ of Na-lactate, and $50 \mathrm{mM}$ of Fe-citrate (adapted from Ginn, Meile, Wilmoth, Tang and Thompson [18]). Cell densities were obtained by optical density measurements at a wavelength of $660 \mathrm{~nm}$ that had been previously calibrated by a direct count of cells using epifluorescence microscopy to reach a population density of over $10^{8} \mathrm{CFU} \mathrm{mL}{ }^{-1}$ [58]. After $S$. oneidensis growth, we conducted a washing procedure twice, by first centrifuging the cells at $3000 \mathrm{RCF}$ for $30 \mathrm{~min}$, discarding the supernatant, and adding a new fresh selective media with the same composition as above, but without yeast extract or Fe-citrate, and then re-doing the centrifugation procedure and disposing the supernatant [18]. In sequence, we added the fresh collected soil with the washed bacterial culture suspended in new fresh selective media (same composition, without yeast extract or Fe-citrate), at a ratio of 1:10 soil:media, in a gas tight tube. In parallel, for the Media-Fe ${ }^{\mathrm{III}}$ RR treatment, we added the fresh soil to the fresh selective media above (without yeast extract or Fe-citrate) and with no S. oneidensis, and placed them in similar gas tight tubes, at a ratio of 1:10 soil:media. For both Shewa- $\mathrm{Fe}^{\mathrm{III}}{ }_{\mathrm{RR}}$ and Media-Fe ${ }_{\mathrm{RR}}^{\mathrm{III}}$, we flushed the tube headspace with inert $\mathrm{N}_{2}$ gas to create anoxic conditions and placed it on an end-over-end shaker for $7 \mathrm{~d}$ in the dark. After $7 \mathrm{~d}$ of incubation, we pipetted $0.5 \mathrm{~mL}$ of either Shewa- $\mathrm{Fe} \mathrm{E}_{\mathrm{RR}}^{\mathrm{III}}$ or Media-Fe ${ }^{\mathrm{III}} \mathrm{RR}$ suspension treatments, centrifuged at 11,000 RCF for $30 \mathrm{~min}$, removed the supernatant, and then revolved and extracted the pellet with $0.5 \mathrm{M}$ of $\mathrm{HCl}$ for $2 \mathrm{~h}$ to obtain $\mathrm{Fe}^{\mathrm{II}}$ concentrations using the ferrozine protocol described above. Results were expressed in mmol Fe $\mathrm{kg}^{-1} \mathrm{~d}^{-1}$ (iron reduction rates), on a dry soil mass basis by calculating the difference in $\mathrm{Fe}^{\mathrm{II}}$ concentrations between day 0 and 7 of the incubation. 


\subsection{Soil Sensors and Data Collection (Measurements within Hours)}

For each site within each of the three catenas, we deployed four platinum electrodes (Paleo Terra Inc., Amsterdam, The Netherlands) adjacent to the plots (Figure S1) measuring the redox potential (Eh) every minute and storing the data every hour via CR23X Campbell data loggers. Measurements of Eh recorded the voltage difference between the reference electrode and a redox electrode (Pt sensor). The Pt sensor was placed for Eh readings at $7.5 \mathrm{~cm}$ depth from the soil surface. Eh values (normalized to $\mathrm{pH} 7, \mathrm{Eh}_{7}$ ) serve as a proxy for four major redox conditions in soils: $\mathrm{Eh}_{7}$ values over $+400 \mathrm{mV}$ indicate oxidizing conditions (aerated soils), $\mathrm{Eh}_{7}$ values between $+100-400 \mathrm{mV}$ indicate moderately reducing conditions, $\mathrm{Eh}_{7}$ values between -100 and $+100 \mathrm{mV}$ indicate reducing conditions, and $\mathrm{Eh}_{7}$ values below $-100 \mathrm{mV}$ indicate highly reducing (anoxic) conditions [60-62]. Eh 7 values around $+300 \mathrm{mV}$ can be considered the boundary between aerobic and anaerobic conditions [63].

At catena- 1 only, volumetric water content $\left(\theta_{V}\right)$, soil oxygen content $\left(\mathrm{O}_{2}\right)$, and fluxes of $\mathrm{CO}_{2}$ and $\mathrm{CH}_{4}$-denoted $\mathrm{F}\left(\mathrm{CO}_{2}\right)$ and $\mathrm{F}\left(\mathrm{CH}_{4}\right)$-were measured near the ridge, slope, and valley sampling plots [36]. Time-domain reflectometry (TDR) probes were used to track volumetric water content, and galvanic Apogee $\mathrm{O}_{2}$ sensors encapsulated in polyvinyl chloride (PVC) chambers were used to track soil $\mathrm{O}_{2}$ concentrations [37]. For each site in catena-1, we deployed five TDR and five $\mathrm{O}_{2}$ sensors installed in the top $15 \mathrm{~cm}$ of the soil, and data was stored every hour in CR1000 Campbell dataloggers. Emissions of $\mathrm{CO}_{2}$ and $\mathrm{CH}_{4}$ were measured using automated flux chambers deployed in each site (three for the valley, three for the slope, and three for the ridge). Gases were collected within the chambers over 10 minutes of sampling, three minutes of flushing between measurements, and automatically transported to a cavity ring down spectroscopy (CRDS) gas analyzer (Picarro, Santa Clara, CA, USA) within the site [36]. Gas samples were collected daily at a maximum of 12 samplings per day per chamber with $\mathrm{F}\left(\mathrm{CO}_{2}\right)$ expressed in $\mu \mathrm{mol} \mathrm{m} \mathrm{m}^{-2} \mathrm{~s}^{-1}$ and $\mathrm{F}\left(\mathrm{CH}_{4}\right)$ in $\mathrm{nmol} \mathrm{m}^{-2} \mathrm{~s}^{-1}$.

\subsection{Statistical Analyses}

The soil characteristics (SRO-Fe, Total-Fe, Total-C, and soil texture) in Table 1 were analyzed using one-way ANOVA followed by Tukey's HSD (honestly significant difference) test at the 5\% probability level in R. We computed models using the daily average for the environmental factors (Eh, $\mathrm{O}_{2}$, and $\theta_{\mathrm{V}}$, measured by sensors) and the daily average precipitation to predict the drivers for Eh, $\mathrm{O}_{2}$, and $\theta_{\mathrm{V}}$ (see initial parameters in Table S4), using the lmer function from the lme4 package in R [64]. We also computed turnover times for the $\mathrm{HCl}$-extractable $\mathrm{Fe}{ }^{\mathrm{II}}$ pool (for both production and consumption) by dividing the $\mathrm{Fe}^{\mathrm{II}}$ concentration by the change of $\mathrm{Fe}^{\mathrm{II}}$ with respect to time between two subsequent sampling points $\left(\tau=\left(\frac{F e_{\text {sample } 1}^{I I}+F e_{\text {sample 2 }}^{I I}}{2}\right) /\left(\frac{F e_{\text {sample 2 }}^{I I}-F e_{\text {sample } 1}^{I I}}{t_{\text {sample } 2}-t_{\text {sample } 1}}\right)\right)$, for an average of all of the sites, as well as for each site individually. We plotted the $\mathrm{HCl}$-extractable $\mathrm{Fe}^{\mathrm{II}}$ turnover times in histograms and reported the most commonly occurring, the mean, and the median turnover time, respectively.

We analyzed the relationship between the biogeochemical measurements using a linear mixed model fit by restricted maximum likelihood (REML), for the sampling days and within the different topographic positions (and sites) of the catenas using the lmer function from the lme4 package in R [64]. The outcome variables that were considered included $\mathrm{Fe}^{\mathrm{II}}, \mathrm{Fe}^{\mathrm{III}}{ }_{\mathrm{RR}}$ (Media or Shewa), DOC, and Eh. We additionally ran models just for catena- 1 to assess relationships between our measurements and the additional sensor measurements $\left(\mathrm{O}_{2}, \theta_{\mathrm{V}}\right)$ and $\mathrm{CO}_{2}$ and $\mathrm{CH}_{4}$ fluxes that were only measured in catena-1. We used a dataset with 17 days of observation spread across 44 days. Predictor variables included DOC, Media-Fe ${ }_{R R}{ }_{\text {III }}, p H, \theta_{G}$, precipitation, and in the case of catena- 1 , also $\mathrm{O}_{2}$ and $\theta_{\mathrm{V}}$ (replacing $\theta_{\mathrm{G}}$ ).

We surmised that the Fe and $\mathrm{C}$ cycling may not respond immediately by changes in precipitation, $\mathrm{Eh}, \mathrm{O}_{2}$, and $\theta_{\mathrm{V}}$, but instead may exhibit a lag (of hours/days) before responding. Thus, we averaged each of these continuously measured variables over different windows of time prior to the time of sampling, and then used a procedure of minimizing Akaike's information criterion (AIC) to select the optimum model (lowest AIC). For precipitation, we compared the averages of one day, two days, three days, four days, five days, and 10 days prior to soil sample collection, and choose the one with the 
lowest AIC (two-day lag; precipitation_48 h). For the Eh, $\mathrm{O}_{2}$, and $\theta_{\mathrm{V}}$ sensors, we compared the AIC at the hour in which the soil sample was taken, and for the average of these sensor readings in the last $2 \mathrm{~h}, 3 \mathrm{~h}, 6 \mathrm{~h}, 12 \mathrm{~h}, 24 \mathrm{~h}, 36 \mathrm{~h}$, and $48 \mathrm{~h}$ before the soil sampling. For example, for a soil sample taken at 14:00 on 14 May 2016 (day 10), we averaged the Eh measurement at 14:00 (Eh_1 h), and then from 13:00 to 14:00 (Eh_2 h), 12:00 to 14:00 (Eh_3 h), and so on until $48 \mathrm{~h}$ prior to the measurement. We reported both AIC and $\mathrm{R}^{2}$ of the models calculated by r.squaredGLMM from the R package MuMIn for generalized linear mixed effects models (GLMMs) $[65,66]$ in order to compare the models.

Table 1. Summary of soil characterization for each catena and topographic position: mean $( \pm 1$ standard error). Lowercase letters $(a, b, c, d)$ indicate significant differences among the variables by ANOVA and Tukey's HSD test at the 5\% probability level. Soils from the Luquillo Experimental Forest (LEF), Puerto Rico, sampled in 2016. SRO: short-range order.

\begin{tabular}{cccccccc}
\hline Site & $\begin{array}{c}\text { SRO-Fe }^{\dagger} \\
\text { mmol kg }^{-1}\end{array}$ & $\begin{array}{c}\text { Total-Fe } \\
\mathbf{m m o l ~ k g}^{-1}\end{array}$ & Carbon (\%) & Clay (\%) & Sand (\%) & Silt (\%) & pH $^{\ddagger}$ \\
\hline Valley-1 & $336(32) \mathrm{a}$ & $1162(10) \mathrm{a}$ & $4.6(0.1) \mathrm{a}$ & $7(0.6) \mathrm{a}$ & $45(3.6) \mathrm{a}$ & $48(1.9) \mathrm{a}$ & $6.1(0.2) \mathrm{a}$ \\
Valley-2 & $305(21) \mathrm{a}$ & $1353(12) \mathrm{b}$ & $4.0(0.2) \mathrm{a}$ & $8(0.7) \mathrm{a}$ & $36(2.7) \mathrm{a}$ & $56(2.1) \mathrm{b}$ & $5.3(0.2) \mathrm{b}$ \\
Valley-3 & $195(10) \mathrm{b}$ & $1409(14) \mathrm{c}$ & $3.1(0.1) \mathrm{b}$ & $10(0.9) \mathrm{b}$ & $33(2.6) \mathrm{b}$ & $56(2.3) \mathrm{b}$ & $5.3(0.1) \mathrm{b}$ \\
Slope-1 & $178(10) \mathrm{b}$ & $1403(12) \mathrm{c}$ & $3.4(0.3) \mathrm{b}$ & $10(0.6) \mathrm{b}$ & $27(3.4) \mathrm{b}$ & $63(2.0) \mathrm{c}$ & $5.1(0.2) \mathrm{bc}$ \\
Slope-2 & $213(7) \mathrm{b}$ & $1503(13) \mathrm{d}$ & $3.1(0.1) \mathrm{b}$ & $12(1.1) \mathrm{b}$ & $28(2.2) \mathrm{b}$ & $60(2.4) \mathrm{c}$ & $4.8(0.2) \mathrm{d}$ \\
Slope-3 & $131(11) \mathrm{c}$ & $1434(12) \mathrm{c}$ & $3.4(0.1) \mathrm{b}$ & $8(0.2) \mathrm{a}$ & $45(1.0) \mathrm{a}$ & $47(0.8) \mathrm{a}$ & $5.1(0.1) \mathrm{bc}$ \\
Ridge-1 & $190(17) \mathrm{b}$ & $1428(12) \mathrm{c}$ & $4.5(0.4) \mathrm{a}$ & $6(0.4) \mathrm{a}$ & $43(4.2) \mathrm{a}$ & $51(1.7) \mathrm{a}$ & $4.9(0.2) \mathrm{d}$ \\
Ridge-2 & $227(9) \mathrm{b}$ & $1334(13) \mathrm{b}$ & $5.9(0.1) \mathrm{c}$ & $5(0.5) \mathrm{a}$ & $52(2.6) \mathrm{ad}$ & $43(2.2) \mathrm{a}$ & $4.8(0.2) \mathrm{d}$ \\
Ridge-3 & $206(6) \mathrm{b}$ & $1340(12) \mathrm{b}$ & $4.6(0.1) \mathrm{a}$ & $5(0.4) \mathrm{a}$ & $60(4.8) \mathrm{cd}$ & $36(1.4) \mathrm{d}$ & $5.0(0.2) \mathrm{cd}$ \\
\hline \multicolumn{7}{c}{ Citrate-Ascorbate Extraction. ${ }^{\ddagger} \mathrm{pH}$ average for all 17 days of soil collection. }
\end{tabular}

\section{Results}

\subsection{Soil Characteristics across Sites}

Soil characteristics (Table 1) varied along the replicated topographic positions. Valley-1 and -2 had the highest SRO-Fe among all of the samples (Table 1). Even with the lowest total-Fe, valley-1 had the highest amount of reactive iron (SRO-Fe) and ferrous iron ( $\left.\mathrm{Fe}^{\mathrm{II}}\right)$ of all of the sites (Table 1). Total-C was high in valley- 1 and -2 and in the ridges, compared to the slopes; thus, there was more $C$ accumulation in the valleys and ridges compared to the slopes (Table 1). Soils had a loam texture for most of the sites, or sandy loam and silt loam for a few sites (Table 1). Detailed results for all of the elements that were analyzed are available in Table S2.

We assessed the similarity of the sites based on a principal component analysis (PCA) of the following triplicated measurements: Total-Fe, SRO-Fe, Total-C, and texture (sand, silt, and clay) (Figure S3). We observed that ridges (R1, R2, R3) are grouped together, reflecting their difference in texture and Total-C content. Likewise, the slopes S1 and S2 could be grouped together based on their fine texture (clay and silt); however, S3 differs in its Fe characteristics. Valley sites V1, V2, and V3 were widely distributed across the different biplot quadrants (Figure S3), not only differing in the second principle component $(\mathrm{V} 1, \mathrm{~V} 2)$ from most of the ridge and slope sites, but also varying in texture and carbon content amongst themselves. Thus, each of the studied valleys had different characteristics, which may be reflected in the higher variation in Eh and other biogeochemical variables between the replicated valleys.

\subsection{Precipitation and Environmental Factors Involved in Redox Processes}

Over the course of the sampling period (May and June 2016), four distinct precipitation-related periods were identified (Figure 1): (1) intermittent rainfall periods of 5-10 $\mathrm{mm}$ every few days (from 3 May to 21 May 2016, phase-1); (2) a short absence of rain/dry period (from 21 May to 26 May 2016, phase-2); (3) an intense rainfall event of $290 \mathrm{~mm}$ for 10 days with a one-day event of $114 \mathrm{~mm}$ (from 27 May to 5 June 2016, phase-3); and (4) a longer dry period of 12 days (from 6 June to 17 June 2016, phase-4) with only one day of rain $(26 \mathrm{~mm})$. These patterns of precipitation directly influence the 
variables that were measured hourly by the sensors $\left(\mathrm{Eh}, \mathrm{O}_{2}\right.$, and $\left.\theta_{\mathrm{V}}\right)$ in most of the sites and catenas (Figures 2 and 3). $\theta_{\mathrm{V}}$ fluctuated closely with precipitation in slope-1 and ridge-1. For example, in slope- $1, \theta_{\mathrm{V}}$ decreased from $0.45 \mathrm{~m}^{3} \mathrm{~m}^{-3}$ to $0.35 \mathrm{~m}^{3} \mathrm{~m}^{-3}$ for the short dry period (phase-2), followed by an increase up to $0.47 \mathrm{~m}^{3} \mathrm{~m}^{-3}$ in the intense rainfall event (phase-3), and decreased again to $0.36 \mathrm{~m}^{3}$ $\mathrm{m}^{-3}$ in the long days without rain (phase-4). Valley-1 had a lower magnitude of soil moisture variation, as water appeared to remain longer in this landscape position (i.e., a poorly drained soil), from $0.45 \mathrm{~m}^{3}$ $\mathrm{m}^{-3}$ to $0.50 \mathrm{~m}^{3} \mathrm{~m}^{-3}$. Soil $\mathrm{O}_{2}$ did not fluctuate much for ridge- 1 and slope- 1 , except for a slight change from $17.5 \% \mathrm{O}_{2}$ to $15.5 \% \mathrm{O}_{2}$ during phase-3. Valley-1 was more responsive to absences of precipitation than ridge- 1 and slope- 1 , with $\mathrm{O}_{2}$ increasing in valley- 1 from $2.5 \%$ to $9.2 \%$ and $1.9 \%$ to $11.8 \%$ for the drying phase-2 and drying phase-4, respectively (Figure 2).

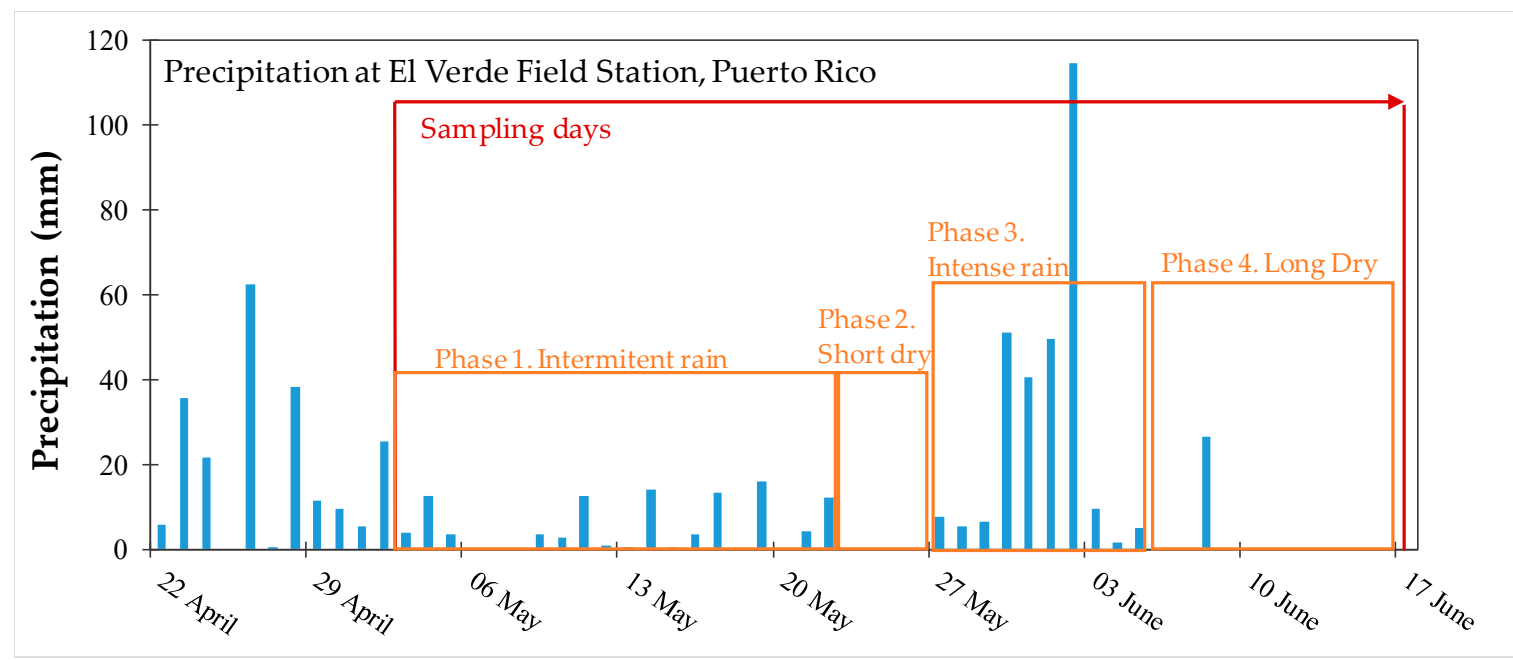

Figure 1. Phases identified during the sampling campaign, with precipitation at the El Verde Field Station, Puerto Rico. Phase-1: 3 May 2016 to 22 May 2016; phase-2: 23 May 2016 to 27 May 2016; phase-3: 28 May 2016 to 5 June 2016; and phase-4: 6 June 2016 to 17 June 2016.

Changes in redox potential had higher amplitude (magnitude) in the valley topographic positions compared to ridges and slopes. In valley-2 (catena-2), the four phases of precipitation (intermittent rain, no rain, intensive rain, and no rain again) were inversely correlated with the Eh $\left(R^{2}=0.944\right)$ (Figure 3): Eh varied between from $\sim 200 \mathrm{mV}$ to $\sim 500 \mathrm{mV}$ within one to two days following rainfall (phase-1), increased from $325 \mathrm{mV}$ to $550 \mathrm{mV}$ during the short dry period (phase-2), and then decreased greatly from $550 \mathrm{mV}$ to $\sim 0 \mathrm{mV}$ during the wet period (phase-3) before increasing back to $550 \mathrm{mV}$ within the final drier days (phase-4). A notable redox fluctuation pattern also occurred in valley-3, with Eh reaching very negative values (from $260 \mathrm{mV}$ to $-360 \mathrm{mV}$ ) during the extreme rainfall event and returning to positive values $(200 \mathrm{mV})$ for the long drier days. However, Eh in valley-1 (catena-1) remained mostly negative $(-500 \mathrm{mV}$ to $-270 \mathrm{mV}$ ) due to high soil moisture (Figure 3). The Eh values that were measured in the three slopes and two ridges across all three catenas remained at values characteristic of oxic conditions (varying from $420 \mathrm{mV}$ to $580 \mathrm{mV}$ ). 

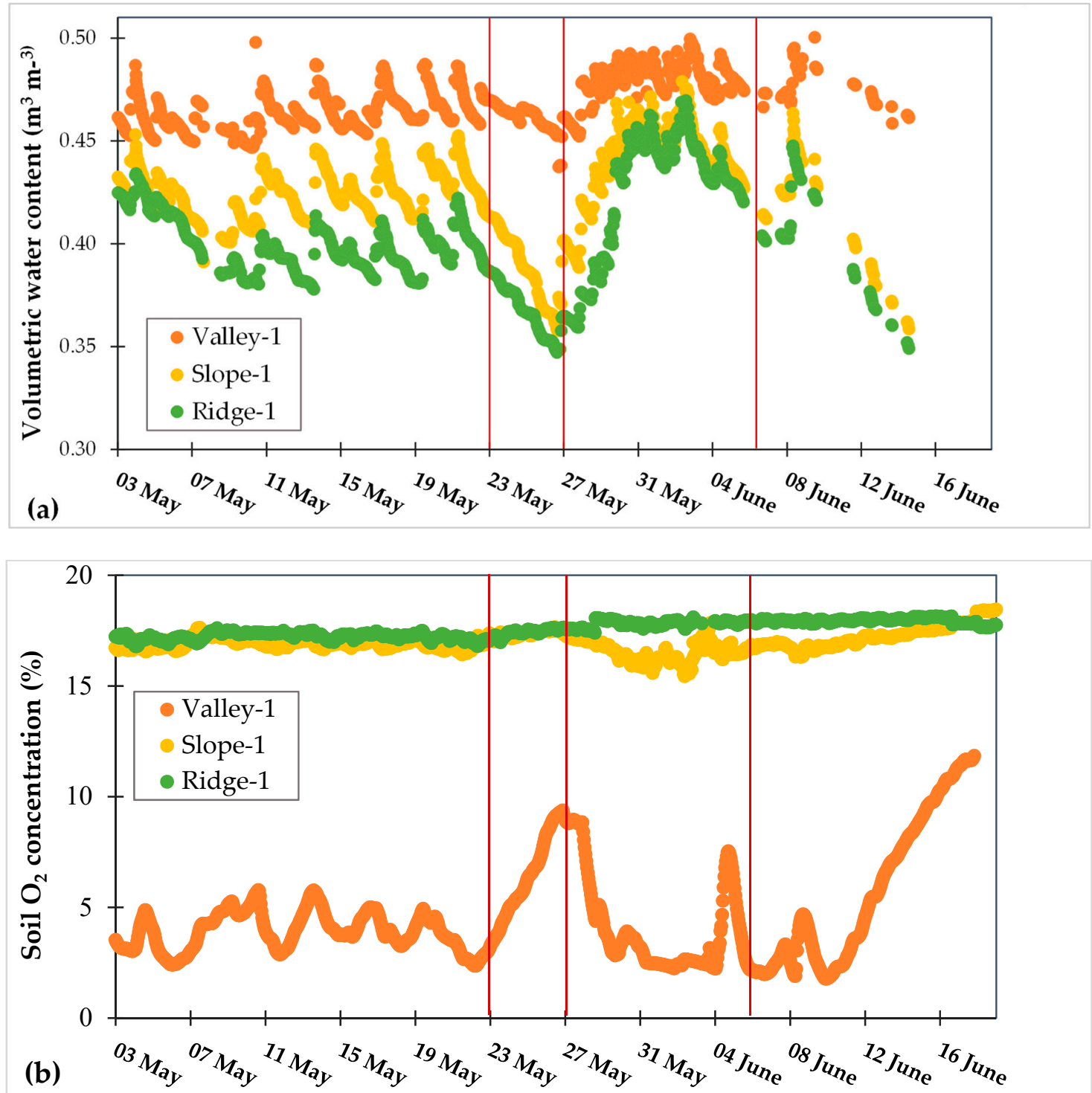

Figure 2. Soil volumetric water content (a) and oxygen (b). Red vertical lines separate the different phases of precipitation (phases 1,2,3, and 4).

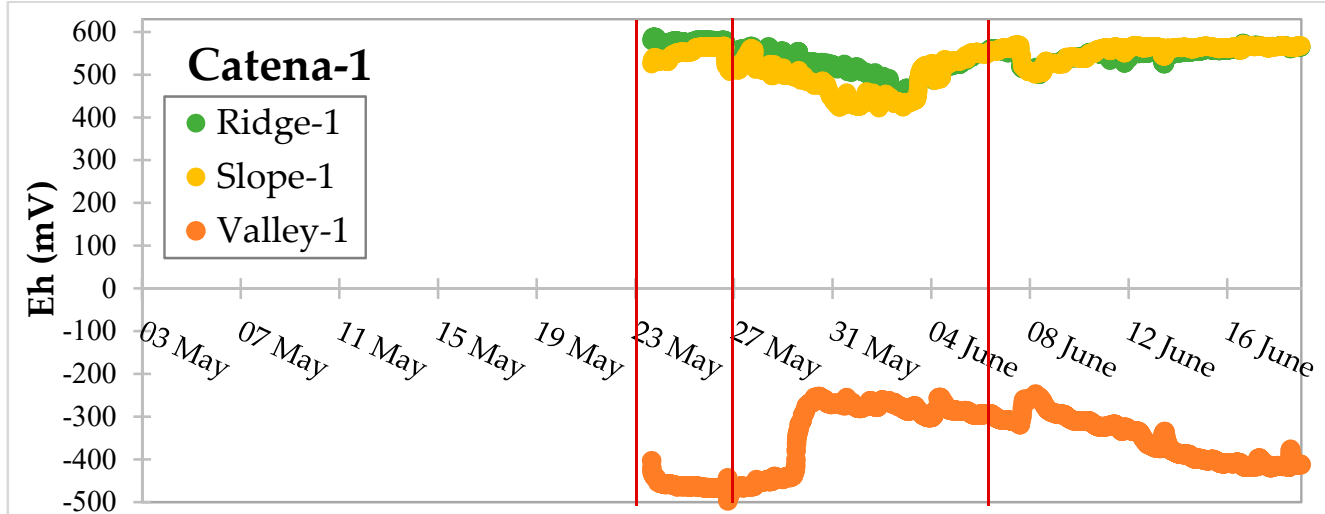

Figure 3. Cont. 


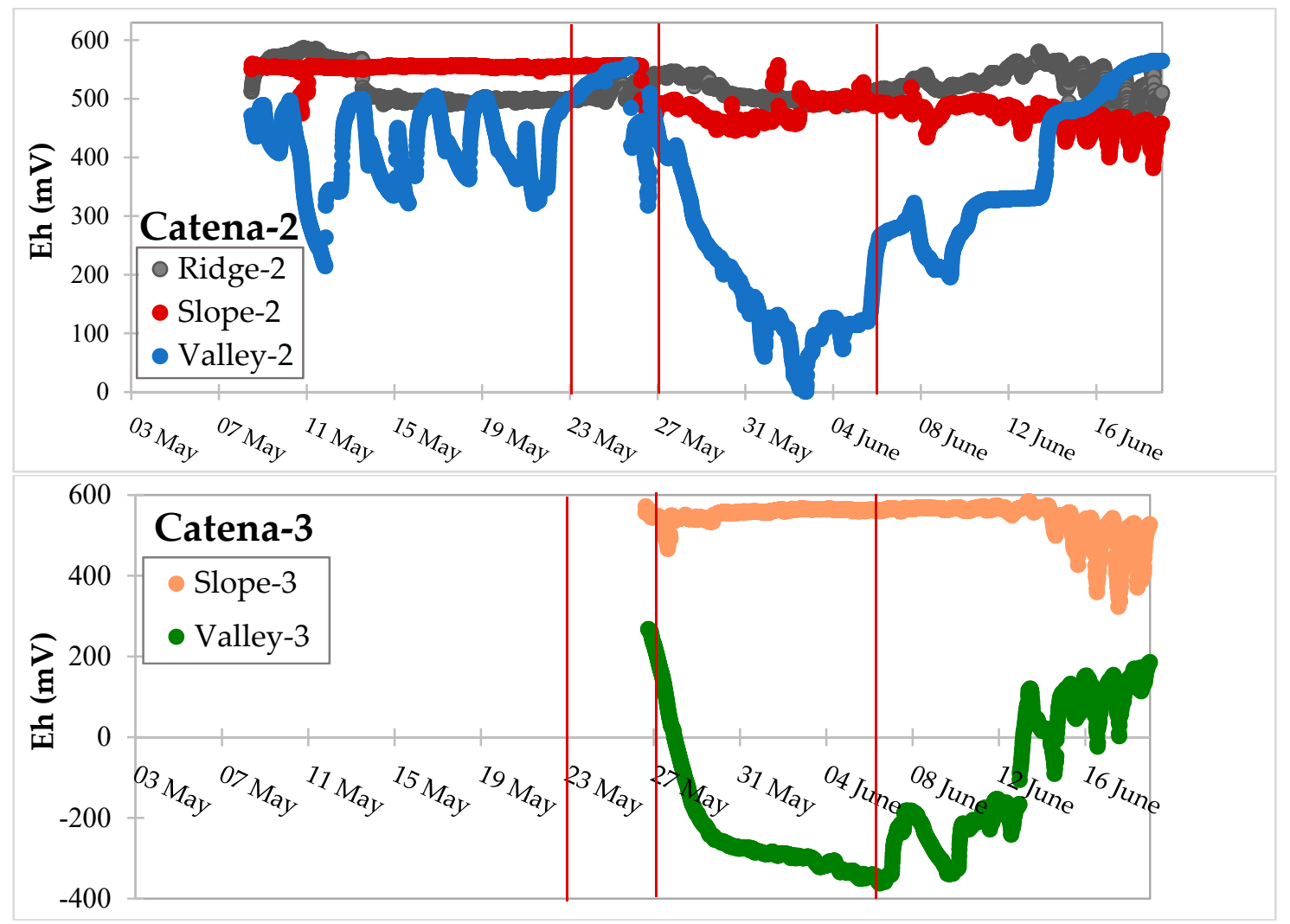

Figure 3. Redox potential (Eh) using platinum electrodes for each site within three catenas. Red vertical lines separate the different phases of precipitation (phases 1, 2,3, and 4).

Using mixed-effects models with stepwise backwards elimination, daily average precipitation was identified as a significant predictor for the daily averages of Eh, $\mathrm{O}_{2}$, and $\theta_{\mathrm{V}}$ (negative, negative, and positive relationships; Table 2). We computed cross-correlations for the averaged daily measurements for the sensors, and we found no time lags between Eh, $\mathrm{O}_{2}$, and $\theta_{\mathrm{V}}$.

Table 2. Summary of mixed-effect linear models for the environmental factors obtained by stepwise backwards elimination. All variables are daily averages.

\begin{tabular}{|c|c|c|c|c|}
\hline Variable & Catenas & $\operatorname{AIC}^{a}\left(R^{2} c\right)^{b}$ & Num. of Observ. ${ }^{c}$ & Model (Significant Predictors in Bold at $p<0.05$ ) \\
\hline Eh & All & $3850.41(0.944)$ & 324 & Precipitation \\
\hline $\mathrm{O}_{2}$ & 1 & $866.20(0.992)$ & 240 & $\mathrm{O}_{2}=-0.0129 \times$ Precipitation \\
\hline$\theta_{\mathrm{V}}$ & 1 & $-880.34(0.853)$ & 213 & $\theta_{\mathrm{V}}=4.894 \times 10^{-4} \times$ Precipitation \\
\hline
\end{tabular}

${ }^{a}$ AIC: Akaike's information criterion; ${ }^{b} \mathrm{R}^{2}$ c: conditional $\mathrm{R}$ squared; ${ }^{\mathrm{c}}$ Maximum number of observations is 415 for all catenas and 243 for Catena 1 only. Units: $\mathrm{Eh}=$ deci-Volts, $\theta_{\mathrm{V}}=\mathrm{m}^{3} \mathrm{~m}^{-3}, \mathrm{O}_{2}=\%$, and Precipitation $=\mathrm{mm}$.

\subsection{Dynamic Biogeochemical Soil Measurements}

Soil extractions for Fe and $\mathrm{C}$ pools also varied over time in response to precipitation and soil moisture. $\mathrm{HCl}$-extractable $\mathrm{Fe}^{\mathrm{II}}$ varied across ridges to slopes to valleys for all three catenas (Figure 4). Valley-1 is wetter and had much higher $\mathrm{Fe}^{\mathrm{II}}$ concentrations compared to all of the other sites in all of the catenas. During the 290-mm intense precipitation period (phase-3), the $\mathrm{Fe}^{\mathrm{II}}$ in valley-1 varied from $50 \mathrm{mmol} \mathrm{kg} \mathrm{kg}^{-1}$ to $126 \mathrm{mmol} \mathrm{kg}{ }^{-1}$. Ridge-2 and slope-2, particularly, had larger variation in $\mathrm{Fe}^{\mathrm{II}}$ concentrations during phase- 3 than the other ridges and slopes, where $\mathrm{Fe}^{\mathrm{II}}$ content increased from $4 \mathrm{mmol} \mathrm{kg}^{-1}$ to $9 \mathrm{mmol} \mathrm{kg}^{-1}$ in ridge-2 and from $3 \mathrm{mmol} \mathrm{kg}^{-1}$ to $8 \mathrm{mmol} \mathrm{kg}^{-1}$ in slope- 2 . During the subsequent 12-day drying event (phase-4), $\mathrm{Fe}^{\mathrm{II}}$ content decreased in most of the sites; for example, from $8 \mathrm{mmol} \mathrm{kg}^{-1}$ to $1 \mathrm{mmol} \mathrm{kg}{ }^{-1}$ in slope-2, and from $4 \mathrm{mmol} \mathrm{kg}^{-1}$ to $1 \mathrm{mmol} \mathrm{kg}^{-1}$ in ridge- 1 and ridge-2. Shewa-Fe ${ }^{\mathrm{III}}{ }_{\mathrm{RR}}$ and Media- $\mathrm{Fe}^{\mathrm{III}}{ }_{\mathrm{RR}}$ were also correlated with high or low rainfall 
events and soil moisture contents varying overall from $1 \mathrm{mmol} \mathrm{kg}-1$ to $50 \mathrm{mmol} \mathrm{kg}^{-1}$ soil day ${ }^{-1}$ (Figure 5). Shewa-Fe ${ }^{\mathrm{III}} \mathrm{RR}$ was correlated with Media- $\mathrm{Fe}^{\mathrm{III}}{ }_{\mathrm{RR}}\left(\mathrm{R}^{2}=0.82\right)$, and both were correlated to $\mathrm{Fe}^{\mathrm{II}}$ concentrations over the course of the experiment, which was consistent with the understanding that $\mathrm{Fe}^{\mathrm{III}}{ }_{\mathrm{RR}}$ measurements assess the pool of $\mathrm{Fe}^{\mathrm{III}}$ that can be rapidly reduced.

DOC did not fluctuate with precipitation $(p=0.610)$ as much as Eh and $\theta_{\mathrm{V}}$ responded to precipitation. Across most of the sites, DOC remained near constant in the intense rainfall period (phase 3) and decreased in the last days of phase-4, with the exception of valley-1; for example, DOC declined from $264 \mathrm{mg} \mathrm{kg}^{-1}$ to $95 \mathrm{mg} \mathrm{kg}^{-1}$ in valley-3, and from $132 \mathrm{mg} \mathrm{kg}^{-1}$ to $114 \mathrm{mg} \mathrm{kg}^{-1}$ in slope-2 during the last drying event (Figure 6). Values of DOC were higher at some of the sampling points (e.g., maximum value of $275 \mathrm{mg} \mathrm{kg}^{-1}$ on 18 May 2016) for valley- 1 than at the other sites, but they were still statistically similar to the DOC of the other sites across the 17 days of soil sampling, despite the higher values of $\mathrm{Fe}^{\mathrm{II}}$ and $\mathrm{Fe}^{\mathrm{III}} \mathrm{RR}$ pool in valley-1. The $\mathrm{pH}$ also did not clearly fluctuate in response to rainfall $(p=0.992)$ and soil moisture $(p=0.180)$ patterns (Figure S4). The $\mathrm{pH}$ (averaged over the 17 sampling days) was higher in the valleys, with values decreasing from 6.1 to 5.1 to 4.9 for valley-1, slope-1, and ridge-1, respectively. This increase in $\mathrm{pH}$ from ridge to slope to valley in catena- 1 is associated with the greater amount of $\mathrm{Fe}^{\mathrm{II}}$, SRO-Fe, and total-C in valley-1. Acidic waterlogged soils commonly exhibit elevated $\mathrm{pH}$ due to the proton consumption during the reduction of nitrate, manganese, and iron [67].

Gravimetric water content $\left(\theta_{\mathrm{G}}\right)$ was somewhat responsive to changes in precipitation (Figure S5). For example, in valley-2 gravimetric water content varied from $0.62 \mathrm{~g} \mathrm{~g}^{-1}$ to $0.84 \mathrm{~g} \mathrm{~g}^{-1}$ for the intense precipitation and decreased to $0.52 \mathrm{~g} \mathrm{~g}^{-1}$ over the next 12 days; however, the volumetric water content (measured hourly by sensors) captured the fluctuations in soil moisture in more detail. Fluxes of $\mathrm{CO}_{2}$ were lower in valley-1 compared to slope- 1 and ridge- 1 , with average values of $0.6 \mu \mathrm{mol} \mathrm{m}{ }^{-2} \mathrm{~s}^{-1}$, $1.6 \mu \mathrm{mol} \mathrm{m} \mathrm{m}^{-2} \mathrm{~s}^{-1}$, and $1.3 \mu \mathrm{mol} \mathrm{m} \mathrm{m}^{-2} \mathrm{~s}^{-1}$ for each of these sites (Figure S6). Valley-1 was a source of $\mathrm{CH}_{4}$, while slope-1 and ridge- 1 were sinks of $\mathrm{CH}_{4}$, with average $\mathrm{CH}_{4}$ fluxes of $3.0 \mathrm{nmol} \mathrm{m} \mathrm{m}^{-2} \mathrm{~s}^{-1}$, $-5.6 \mathrm{nmol} \mathrm{m}^{-2} \mathrm{~s}^{-1}$, and $-0.4 \mathrm{nmol} \mathrm{m}^{-2} \mathrm{~s}^{-1}$, respectively (Figure S6).

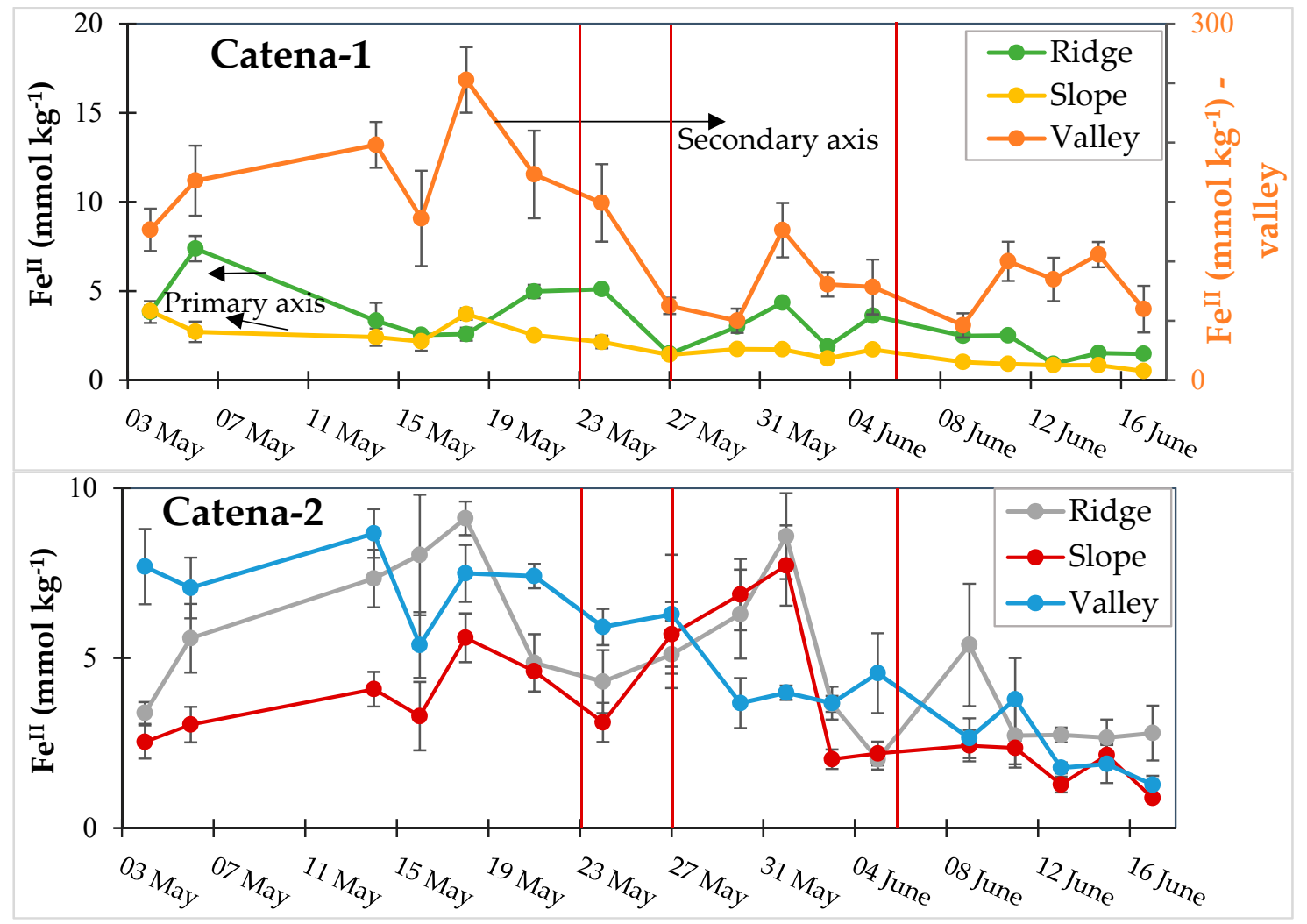

Figure 4. Cont. 


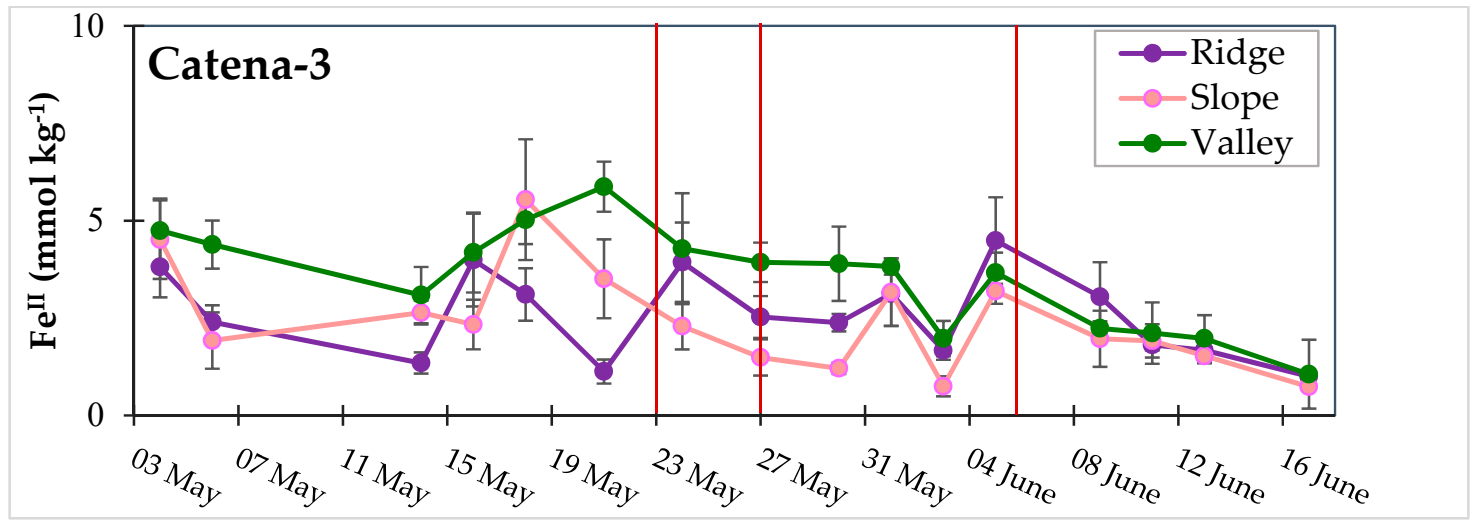

Figure 4. $\mathrm{Fe}^{\mathrm{II}}$ at the ridge, slope, and valley for all three catenas. Error bars are $\pm 1 \mathrm{SD}$. Red vertical lines separate the different phases of precipitation (phases 1,2,3, and 4).
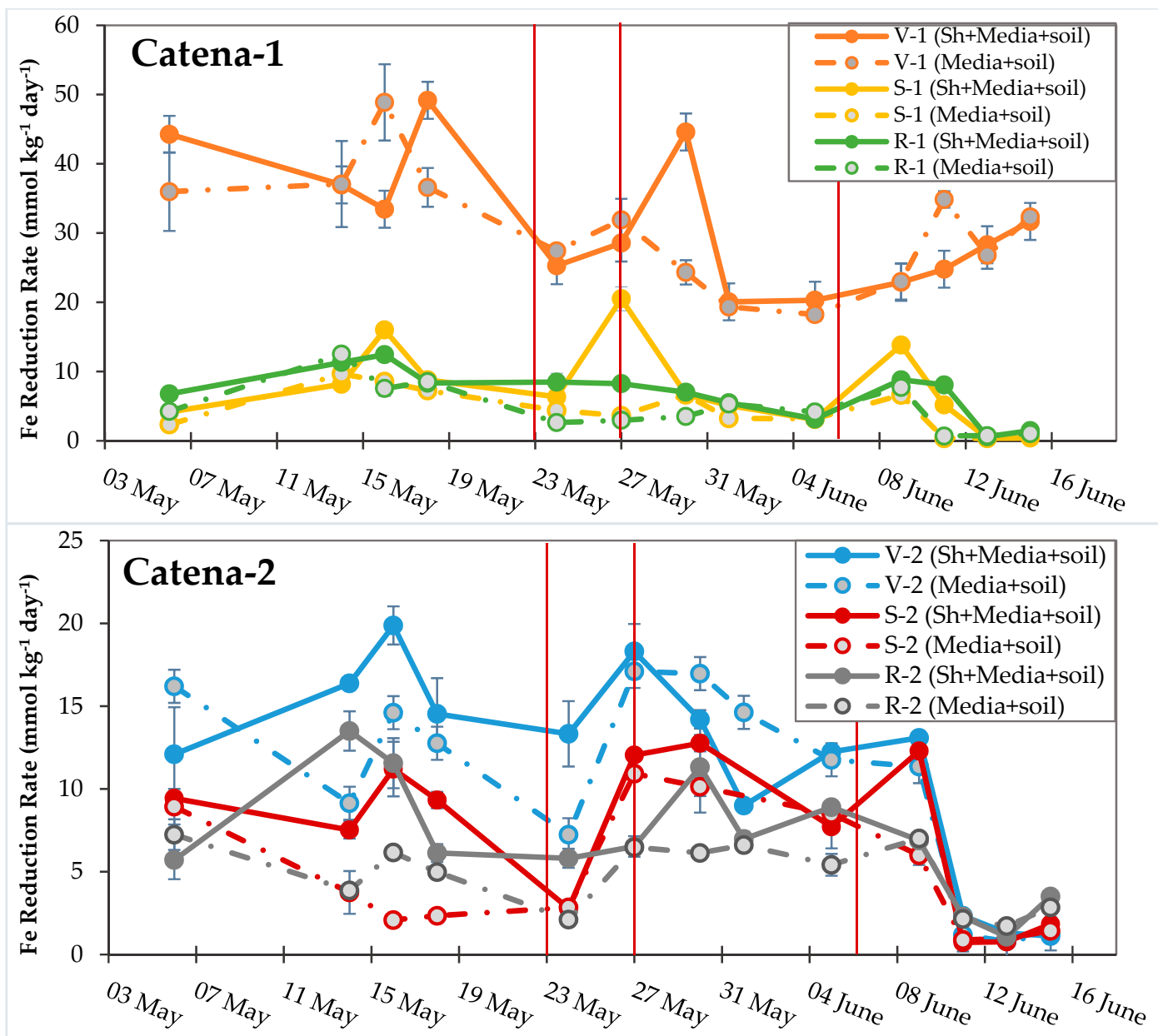

Figure 5. Cont. 


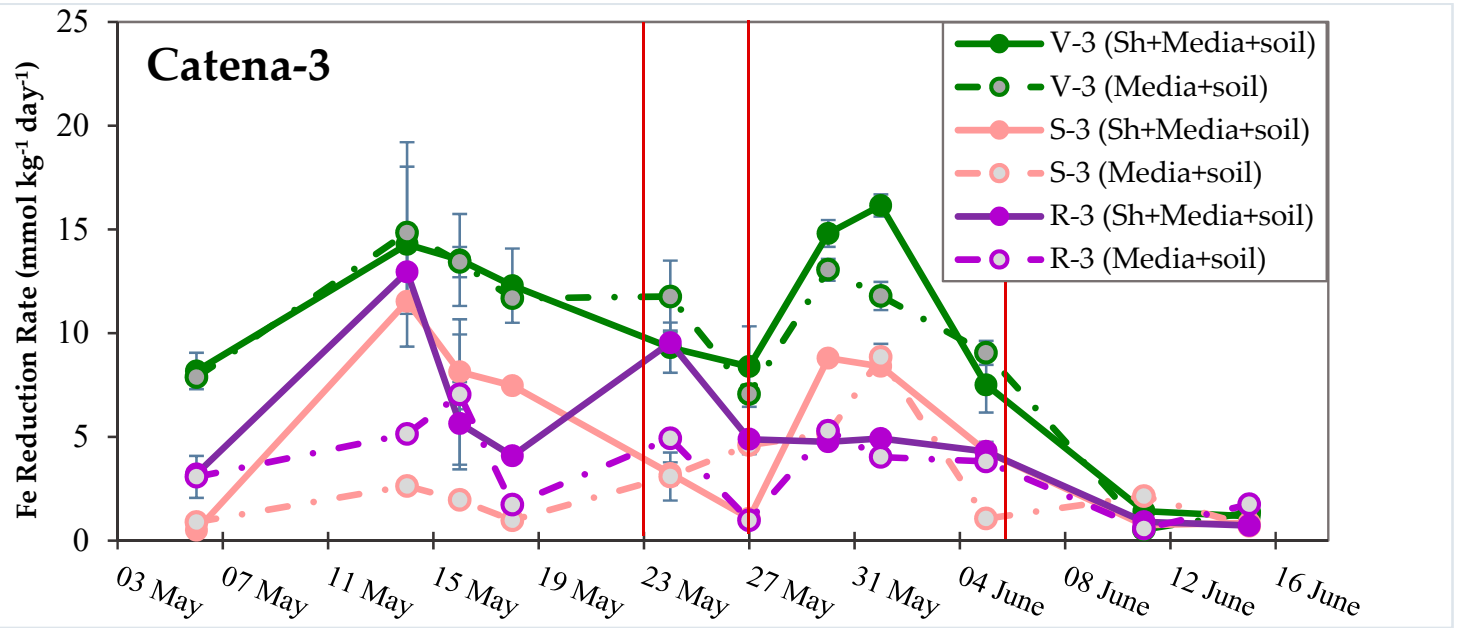

Figure 5. Soil Fe reduction rates (seven days) by Shewanella+media (Shewa-Fe ${ }_{\text {RR }}^{\mathrm{III}}$ ) or media only (Media-Fe $\mathrm{III}_{\mathrm{RR}}$ ) incubations. Error bars are $\pm 1 \mathrm{SD}$. Red vertical lines separate the different phases of precipitation (phases 1, 2, 3, and 4).
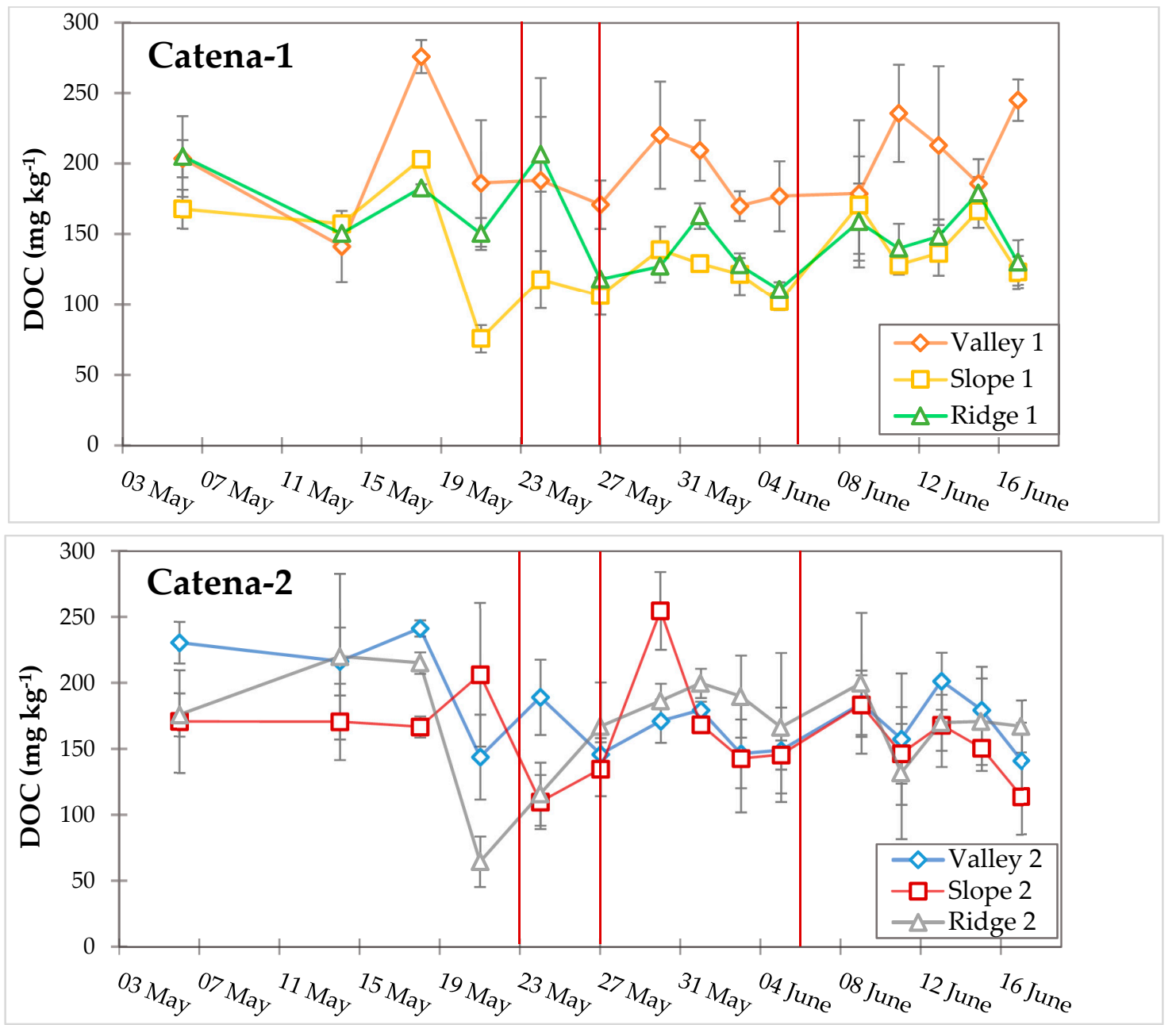

Figure 6. Cont. 


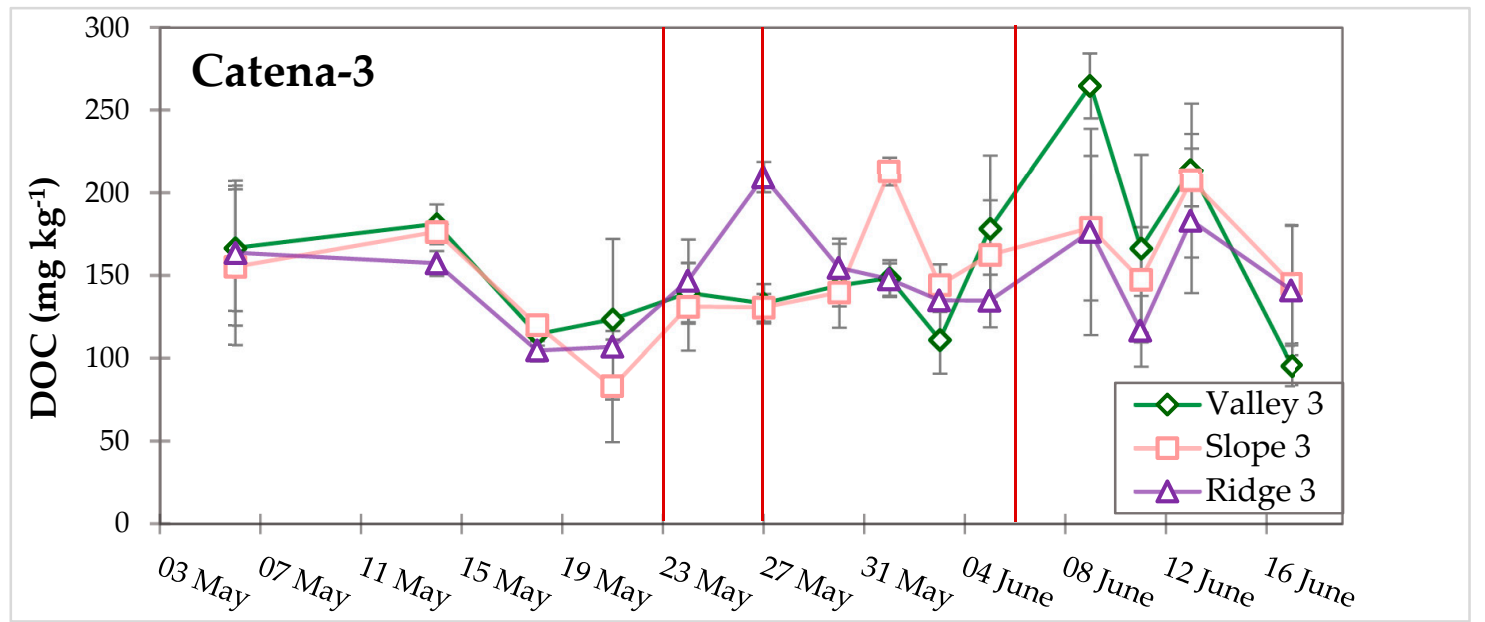

Figure 6. Dissolved organic carbon (DOC), 1:5 soil:water extraction. Error bars are \pm 1 SD. Red vertical lines separate the different phases of precipitation (Phases 1, 2, 3, and 4).

\subsection{Turnover Timescales for HCl-Extractable Fe ${ }^{I I}$ Pool and Statistical Models to Predict Soil Biogeochemical Parameters}

Across all nine sites within the three catenas, the most common turnover time for the $\mathrm{HCl}$-extractable $\mathrm{Fe}^{\mathrm{II}}$ pool during net production was four days, and during the net $\mathrm{HCl}$-extractable $\mathrm{Fe}^{\mathrm{II}}$ consumption was three to four days; only in a few instances were longer turnover times measured (Figure 7, Table S3). We determined the optimal mixed-effects models for the biogeochemical variables $\mathrm{Fe}^{\mathrm{II}}$, Media-Fe ${ }^{\mathrm{III}}{ }_{\mathrm{RR}}$, Shewa-Fe ${ }_{\mathrm{RR}}^{\mathrm{III}}, \mathrm{DOC}, \mathrm{F}\left(\mathrm{CO}_{2}\right)$, and $\mathrm{F}\left(\mathrm{CH}_{4}\right)$ (Table 3) using stepwise backwards elimination, which removes all of the non-significant variables one by one, and keeps only the significant variables in the final elimination step (see initial parameters in Table S4). We chose the model with the lowest AIC (best model) by comparing the average of the measurements taken for Eh, $\mathrm{O}_{2}$ and $\theta_{\mathrm{V}}$ from $1 \mathrm{~h}, 2 \mathrm{~h}, 3 \mathrm{~h}, 6 \mathrm{~h}, 12 \mathrm{~h}, 24 \mathrm{~h}, 36 \mathrm{~h}$, and $48 \mathrm{~h}$ preceding the time and date when the soil samples were taken. In the model predicting DOC concentration, the lowest AIC was the model with $\mathrm{O}_{2}$ averaged over the preceding $48 \mathrm{~h}$ from the measurement $\left(\mathrm{O}_{2}-48 \mathrm{~h}\right)$ (Table S5). For precipitation, we used the two-day (or 48-h) averaged precipitation, which had the lowest AIC (Precipitation_48 h), compared to the averages of one, three, four, five, and 10 days prior to soil sampling. The two-day averaged precipitation was also found to be the time lag between the precipitation, the studied environmental factors, and biogeochemical variables.

Values of $\mathrm{Fe}^{\mathrm{III}}{ }_{\mathrm{RR}}$ and $\mathrm{pH}$ were positively correlated with $\mathrm{Fe}^{\mathrm{II}}$ levels for all of the catenas (all nine sites) $\left(\mathrm{R}^{2}=0.727\right)$, and $\mathrm{O}_{2}$ was negatively correlated with $\mathrm{Fe}^{\mathrm{II}}$ concentrations for the sites in catena-1 (Table 3) $\left(R^{2}=0.789\right)$. We used Media-Fe ${ }^{I I I}{ }_{R R}$ (and not Shewa-Fe ${ }^{I I I}{ }_{R R}$ ) for the Fe ${ }^{I I I}$ models, because Media-Fe ${ }^{\mathrm{III}}{ }_{R R}$ had the lowest AIC compared to Shewa-Fe ${ }^{\mathrm{III}}{ }_{\mathrm{RR}}$ or both Media-Fe ${ }^{\mathrm{III}}{ }_{\mathrm{RR}}$ and Shewa-Fe ${ }^{\mathrm{III}}{ }_{R R}$ together in the model. Gravimetric water content $\left(\theta_{\mathrm{G}}\right)$ and $\mathrm{Fe}^{\mathrm{II}}$ were positively correlated in both Media-Fe ${ }^{\mathrm{III}}{ }_{\mathrm{RR}}$ and Shewa-Fe ${ }_{\mathrm{RR}}^{\mathrm{III}}$ models $\left(\mathrm{R}^{2}=0.835\right.$ and 0.810 , respectively). Thus, Media-Fe ${ }^{\mathrm{III}}{ }_{\mathrm{RR}}$ and Shewa-Fe ${ }^{\mathrm{III}} \mathrm{RR}$ were indirectly driven by changes in precipitation. Eh was negatively correlated to Media-Fe ${ }^{\mathrm{III}}$ RR, and $\mathrm{pH}$ was positively correlated to Shewa-Fe ${ }^{\mathrm{III}} \mathrm{RR}$ for all of the catenas (Table 3). DOC was positively correlated to $\theta_{\mathrm{G}}$ and $\mathrm{Fe}^{\mathrm{II}}\left(\mathrm{R}^{2}=0.441\right)$. The $\mathrm{F}\left(\mathrm{CO}_{2}\right)$ was negatively correlated to $\theta_{\mathrm{V}}$ (Table 3) $\left(\mathrm{R}^{2}=0.429\right)$. For $\mathrm{F}\left(\mathrm{CH}_{4}\right)$ models, we observed that the regression results were significantly impacted by five outlier values, and by removing these outliers, we observed a positive correlation of $\mathrm{F}\left(\mathrm{CH}_{4}\right)$ and $\mathrm{pH}$ (Figure S7) $\left(\mathrm{R}^{2}=0.545\right)$. 


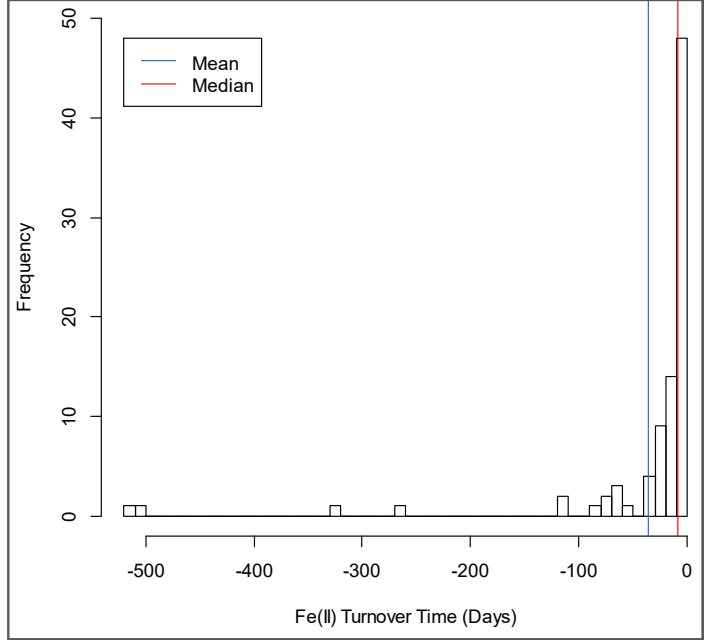

(a)

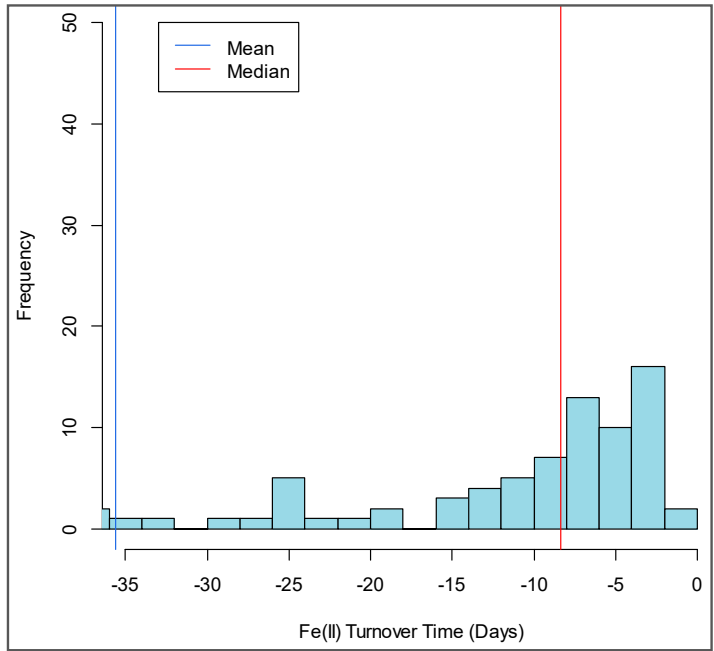

(b)

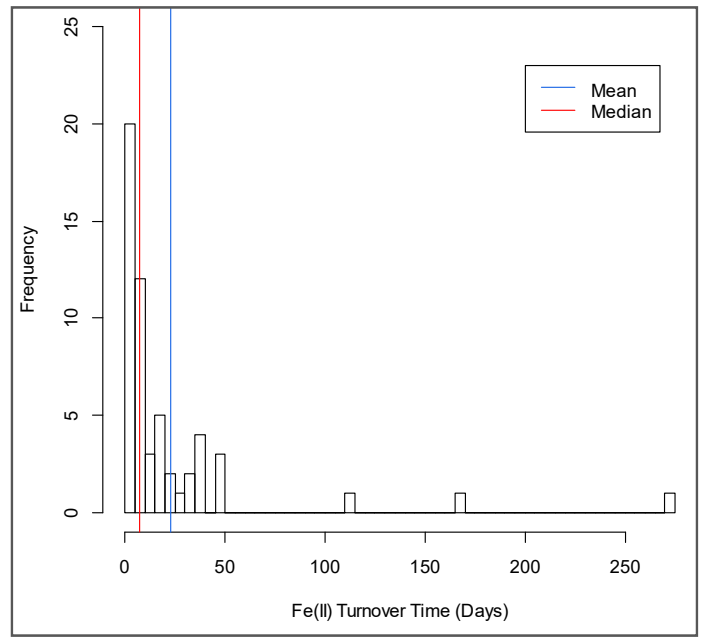

(c)

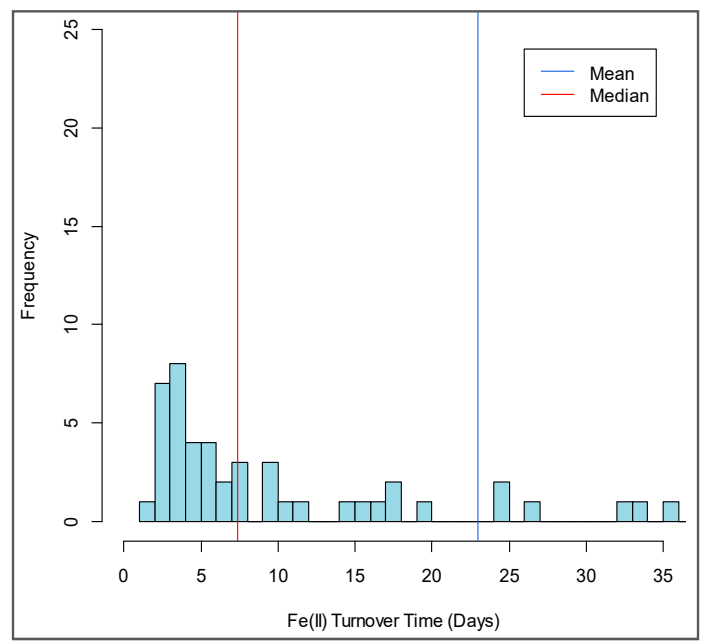

(d)

Figure 7. Turnover times for $\mathrm{HCl}$-extractable $\mathrm{Fe}^{\mathrm{II}}$ consumption $(\mathbf{a}, \mathbf{b})$ and $\mathrm{Fe}^{\mathrm{II}}$ production $(\mathbf{c}, \mathbf{d})$ averaged for all sites. Figure $(\mathbf{b}, \mathbf{d})$ are equivalent to figure $(\mathbf{a}, \mathbf{c})$, respectively, but with tighter $x$-axis scales.

Table 3. Summary of mixed-effect linear models for the biogeochemical variables obtained by stepwise backwards elimination.

\begin{tabular}{|c|c|c|c|c|}
\hline Variable & Catenas & $\operatorname{AIC}^{a}\left(R^{2} c\right)^{b}$ & Num. of Observ. ${ }^{c}$ & Model (Significant Predictors in Bold at $p<0.05$ ) \\
\hline \multirow[t]{2}{*}{$\mathrm{Fe}^{\mathrm{II}}$} & All & $990.725(0.727)$ & 110 & $\mathrm{Fe}^{\mathrm{II}}=2.130 \times$ Media-Fe ${ }^{\mathrm{III}}{ }_{\mathrm{RR}}+20.286 \times \mathbf{p H}$ \\
\hline & Catena 1 & $377.89(0.789)$ & 39 & $\mathrm{Fe}^{\mathrm{II}}=2.4758 \times$ Media-Fe $\mathrm{III}_{\mathrm{RR}}^{\mathrm{II}}-4.3644 \times \mathrm{O}_{2} \_48 \mathrm{~h}$ \\
\hline Media-Fe $\mathrm{e}_{\mathrm{RR}}$ & All & $413.32(0.835)$ & 73 & Media-Fe $\mathrm{e}_{\mathrm{RR}}^{\mathrm{III}} \sim 0.1073 \times \mathbf{F e}^{\mathrm{II}}+20.295 \times \theta_{\mathrm{G}}-0.845 \times \mathbf{E h} \_\mathbf{6} \mathbf{h}$ \\
\hline Shewa-Fe ${ }^{\text {IIII }}{ }_{R R}$ & All & $654.06(0.810)$ & 110 & Shewa-Fe ${ }^{\mathrm{III}} \mathrm{RR} \sim 0.1202 \times \mathrm{Fe}^{\mathrm{II}}+21.221 \times \theta_{\mathrm{G}}+3.861 \times \mathbf{p H}$ \\
\hline DOC & All & $718.68(0.441)$ & 132 & $\mathrm{DOC}=0.1909 \times \mathrm{Fe}^{\mathrm{II}}+12.47 \times \theta_{\mathrm{G}}$ \\
\hline Flux $\mathrm{CO}_{2}$ & Catena 1 & $117.2(0.429)$ & 45 & $\mathrm{~F}\left(\mathrm{CO}_{2}\right)=-10.995 \times \theta_{\mathrm{V}}$ \\
\hline
\end{tabular}

${ }^{a}$ AIC: Akaike's information criterion; ${ }^{b} R^{2} \mathrm{c}$ : conditional $\mathrm{R}$ squared; ${ }^{\mathrm{c}}$ Maximum number of observations is 153 for all catenas and 51 for Catena 1 only. Units: $\mathrm{Fe}^{\mathrm{II}}=\mathrm{mmol} \mathrm{kg}{ }^{-1}$, Media-Fe $\mathrm{FII}_{\mathrm{RR}}$ and Shewa-Fe $\mathrm{III}_{\mathrm{RR}}=\mathrm{mmol} \mathrm{kg}^{-1} \mathrm{~d}^{-1}$, $\mathrm{DOC}=\mathrm{mg} \mathrm{kg}^{-1} ; \mathrm{pH}=$ unitless; $\theta_{\mathrm{G}}=\mathrm{g} \mathrm{g}^{-1} ; \mathrm{Eh}=$ deci-Volts, $\theta_{\mathrm{V}}=\mathrm{m}^{3} \mathrm{~m}^{-3}, \mathrm{O}_{2}=\%, \mathrm{~F}\left(\mathrm{CO}_{2}\right)=\mu \mathrm{mol} \mathrm{m}^{-2} \mathrm{~s}^{-1}$, and $\mathrm{F}\left(\mathrm{CH}_{4}\right)=\mathrm{nmol} \mathrm{m}{ }^{-2} \mathrm{~s}^{-1}$

\section{Discussion}

\subsection{Turnover Times for HCl-Extractable Fe $\mathrm{II}^{\mathrm{II}}$ Pool and Drivers of Fe Redox Processes}

We aimed to measure the timescales for the turnover of the $\mathrm{HCl}$-extractable $\mathrm{Fe}^{\mathrm{II}}$ pool, in order to understand the controls on $\mathrm{Fe}^{\mathrm{II}}$ biogeochemical cycling, and capture hot moments (of hours to days) 
and identify hot spots for Fe cycling. Our field timeseries measurements revealed that $\mathrm{HCl}$-extractable $\mathrm{Fe}^{\mathrm{II}}$ turnover times that were calculated using consumption or production were centered around four days across ridges, slopes, and valleys. These results compare favorably to our prior controlled laboratory experiment [68], where the mean turnover for the $\mathrm{HCl}$-extractable $\mathrm{Fe}^{\mathrm{II}}$ pool that was calculated based on production varied from three to five days, and based on consumption from 0.5 to five days (this is likely faster than in the field because the laboratory experiments were slurry incubations). To our knowledge, there are no prior reports of $\mathrm{Fe}^{\mathrm{II}}$ turnover times for soils under natural conditions, but turnover times can be calculated for some coastal marine systems [69-71]. For example, Wang and Van Cappellen [69] reported rates of dissimilatory Fe reduction and $\mathrm{Fe}^{\mathrm{II}}$ concentrations (adsorbed $\mathrm{Fe}^{\mathrm{II}}$ and $\mathrm{Fe}^{\mathrm{II}} \mathrm{CO}_{3}$ ) for coastal marine sediments. From these values, we estimated that the turnover time for $\mathrm{Fe}^{\mathrm{II}}$ pool was between 91-120 days. Thus, the $\mathrm{Fe}^{\mathrm{II}}$ turnover according to these models are at least an order of magnitude longer than our results for the LEF soils, suggesting that these humid tropical soils exhibit rapid rates of $\mathrm{Fe}^{\mathrm{II}}$ turnover.

Our mixed-effect models suggest that Fe reduction and oxidation, as measured by $\mathrm{HCl}$-extracted $\mathrm{Fe}^{\mathrm{II}}$ concentrations, are driven by $\mathrm{O}_{2}, \mathrm{pH}$, and the pool of rapidly reducible $\mathrm{Fe}^{\mathrm{III}}$ oxides $\left(\mathrm{Fe}^{\mathrm{III}} \mathrm{RR}\right)$. We interpret this correlation as follows. At the soil $\mathrm{pH}$ and $\mathrm{O}_{2}$ content measured at the field sites, $\mathrm{Fe}^{\mathrm{II}}$ concentrations are responsive to the pool of $\mathrm{Fe}^{\mathrm{III}}$ oxides that are readily available for reduction, and are measured using either native soil microorganisms or via amendment with non-native bacteria (Shewanella sp.), the Media-Fe ${ }^{\mathrm{III}} \mathrm{RR}$ and Shewa- $\mathrm{Fe}^{\mathrm{III}}{ }_{\mathrm{RR}}$, respectively. Although soil moisture was not a predictor in the final $\mathrm{Fe}^{\mathrm{II}}$ model, $\theta_{\mathrm{G}}$ was a predictor for the rapidly reducible $\mathrm{Fe}^{\mathrm{III}}$ oxides (Media-Fe $\mathrm{Fe}_{\mathrm{RR}}^{\mathrm{III}}$, in this case), which strongly impact the availability of $\mathrm{Fe}^{\mathrm{II}}$ in soils. These findings corroborate our first hypothesis that precipitation is driving $\mathrm{O}_{2}$ and soil moisture, and those parameters are in turn driving the $\mathrm{Fe}^{\mathrm{III}}$ RR pool; thus, both $\mathrm{O}_{2}$ and $\mathrm{Fe}^{\mathrm{III}}$ RR control $\mathrm{Fe}^{\mathrm{II}}$ concentrations, under the measured environmental conditions and soil $\mathrm{pH}$ at the field sites. So that, precipitation and soil moisture indirectly influenced Fe reduction and oxidation in soils from the LEF. These results agree with previous work demonstrating that a dissimilatory Fe reduction was controlled by environmental factors such as soil $\mathrm{O}_{2}$ and water content, and the inherent soil Fe mineral composition [11,19,72].

In support of our second hypothesis that the valleys exhibit different Fe dynamics than other topographic positions, valley-1 contained much higher (and statistically different, $p<0.05$ ) $\mathrm{Fe}^{\mathrm{II}}$ concentrations ( $50 \mathrm{mmol} \mathrm{kg}^{-1}$ to $126 \mathrm{mmol} \mathrm{kg}^{-1}$ ) and $\mathrm{Fe}^{\mathrm{III}} \mathrm{RR}$ rates $\left(18 \mathrm{mmol} \mathrm{kg}{ }^{-1}\right.$ to $49 \mathrm{mmol}$ $\mathrm{kg}^{-1} \mathrm{~d}^{-1}$ ) than the other two valleys and all of the other ridges and slopes. However, for other biogeochemical variables, such as DOC, the values did not vary among the topographic positions. Thus, valley-1 was a hot spot for Fe biogeochemical processes compared to all other sites, and the other valleys (such as valley-2 and valley-3) may also generally serve as hot spots of Fe cycling.

To understand the redox processes across different landscape positions, complementary variables such as Eh, soil $\mathrm{O}_{2}$, and bulk soil extractions for $\mathrm{Fe}^{\mathrm{II}}$ (as an indicator of reducing conditions) can be used to assess the redox status of the environment. Eh measurements are suitable for soils that are consistently wet (such as the soil within valleys 1,2 , and 3 ). We observed a more pronounced variation in soil Eh in valley-2 and valley- 3 than in valley- 1 , which followed similar trends in precipitation, soil moisture, and $\mathrm{O}_{2}$ (valley-1 was constantly anoxic, with highly negative Eh values). Given the relatively constant negative Eh values in Valley-1, we investigated Eh models using only valley-2 and valley-3, which had greater variance in Eh in response to precipitation. In these analyses, we found a significant negative correlation $(p<0.05)$ between $\mathrm{Fe}^{\mathrm{II}}$ and $\mathrm{Eh}$. Thus, in some valley positions, the variations in redox potential $(\mathrm{Eh})$ can be directly correlated with Fe reduction.

In our recent laboratory experiments incubating soil slurries from a similar valley topographic position in the LEF (Bisley watershed), we explored changes in $\mathrm{Fe}^{\mathrm{II}}$ due to redox fluctuation parameters, such as the magnitude (or amplitude) of $\mathrm{O}_{2}$, frequency/periodicity, and time length under oxic and anoxic conditions $[18,49,73,74]$. In these incubations, we found that the magnitude and periodicity of redox fluctuations influence $\mathrm{Fe}$ and $\mathrm{C}$ dynamics with clear patterns of Fe reduction during anoxia and Fe oxidation during oxic conditions. Indeed, the number of hours and days for the natural redox 
fluctuations in valleys 2 and 3 (such as the notable changes in Eh), and the soil sampling periodicity we have done in the field, are comparable to the imposed 2.5 days, six days, and 10 days of anoxic conditions in the laboratory experiment [49].

\subsection{The Dynamic Pool of Rapidly Reducible Fe Oxides ( $F e^{I I I}{ }_{R R}$ )}

We conducted soil incubations to assess the abundance of reactive $\mathrm{Fe}^{\mathrm{III}}$ that is readily available for bacteria (Media-Fe $\mathrm{FII}_{\mathrm{RR}}$ and Shewa- $\mathrm{Fe}^{\mathrm{III}} \mathrm{RR}$ ) as a bioreduction alternative to the selective chemical extractions such as citrate-ascorbate, oxalate, and hydroxylamine, e.g., Coward, et al. [75], Ginn, Meile, Wilmoth, Tang and Thompson [18], and Hall and Silver [35], which are generally thought to be static over month to year timescales. We found that both Media-Fe ${ }^{\mathrm{III}} \mathrm{RR}$ and Shewa-Fe ${ }^{\mathrm{III}}$ RR were positively correlated with $\theta_{\mathrm{G}}$ and $\mathrm{Fe}^{\mathrm{II}}$. Media-Fe ${ }^{\mathrm{III}}{ }_{\mathrm{RR}}$ was negatively correlated with $\mathrm{Eh}$, and Shewa-Fe ${ }^{\mathrm{III}}{ }_{\mathrm{RR}}$ was positively correlated with $\mathrm{pH}$. The observed values of Shewa- $\mathrm{Fe}^{\mathrm{III}}{ }_{\mathrm{RR}}$ were generally similar to Media-Fe ${ }^{\mathrm{III}}{ }_{\mathrm{RR}}$ values for valley-1 and valley-3. However, in the ridges and slopes, the values for Shewa-Fe ${ }^{I I I}$ RR were generally higher than the values for Media-Fe ${ }^{I I I}$ RR. These bioreduction results indicate that valleys can be nutrient and C-deficient for Fe reduction (as $\mathrm{Fe}^{\mathrm{III}}{ }_{\mathrm{RR}}$ and SRO-Fe pools can be abundant), and slopes and ridges can be deficient in nutrients, $\mathrm{C}$, and reactive Fe phases ( $\mathrm{Fe}^{\mathrm{III}}{ }_{\mathrm{RR}}$ ) (Figure 5).

We found that both Shewa-Fe ${ }^{\mathrm{III}}$ RR and Media-Fe ${ }^{\mathrm{III}}$ RR changed in response to rainfall and soil moisture. For example, averaged over the 17 time points, Shewa-Fe ${ }^{\mathrm{III}} \mathrm{RR}$ and Media-Fe ${ }^{\mathrm{III}}{ }_{\mathrm{RR}}$ accounted for between 17-66 \% and 12-64 \% of the SRO-Fe pool, respectively, and reached a maximum value of $\sim 100 \%$ of the SRO-Fe pool in some instances (Table S6). We also observed an overall increase in the $\mathrm{Fe}^{\mathrm{III}} \mathrm{RR} / \mathrm{SRO}-\mathrm{Fe}$ ratio from ridges to slopes to valleys (Table S6). Thus, in our study, the valleys likely had a greater fraction of SRO-Fe that was readily available for use as an electron-acceptor (i.e., $\mathrm{Fe}^{\mathrm{III}} \mathrm{RR}_{\text {) }}$ relative to the slopes and ridges.

We propose that the pool of rapidly reducible $\mathrm{Fe}^{\mathrm{III}}$ is a more dynamic and fluctuating pool than typically understood through selective extractions such as citrate-ascorbate or hydroxylamine [35,75]. While the full SRO-Fe pool as measured by these selective extractions may approximate the total amount of reducible $\mathrm{Fe}^{\mathrm{III}}$, this does not represent the $\mathrm{Fe}^{\mathrm{III}}$ pool that can be reduced within short timescales, such as days and weeks. For instance, Ginn, Meile, Wilmoth, Tang and Thompson [18] observed that the SRO-Fe abundance was a poor predictor of Fe reduction rates, whereas measurements of $\mathrm{Fe}^{\mathrm{III}} \mathrm{RR}$ via an incubation with an Fe-reducing microorganism were able to explain the difference in Fe reduction rates in the treatments. This rapidly reducible $\mathrm{Fe}^{\mathrm{III}}$ pool $\left(\mathrm{Fe}^{\mathrm{III}} \mathrm{RR}\right)$ is certainly a subset of the larger SRO. It likely comprises the least crystalline and most soluble portion of the SRO pool, but it may also be that it represents SRO Fe phases that are simply in closer proximity to the Fe-reducing organisms. The rapid oxidation of $\mathrm{Fe}^{\mathrm{II}}$ results in $\mathrm{Fe}^{\mathrm{III}}$ phases that are more reducible (and of lower crystallinity) than bulk Fe ${ }^{\mathrm{III}}$ phases [73], but the presence of mineral surfaces and organic matter alter this crystallinity independent from the oxidation rate [30]. This suggests that frequent oxidation and reduction events may increase the proportion of $\mathrm{Fe}^{\mathrm{III}} \mathrm{RR}$ relative to the total SRO-Fe pool. Our work here supports this hypothesis, but also suggests that the $\mathrm{Fe}^{\mathrm{III}}{ }_{\mathrm{RR}}$ pool is quite dynamic and can vary considerably in response to multiple environmental forces. For example, in two distinct days of sampling for valley-1, the $\mathrm{Fe}^{\mathrm{III}} \mathrm{RR}$ pool varied from $140 \mathrm{mmol} \mathrm{kg}^{-1}$ to $336 \mathrm{mmol} \mathrm{kg}^{-1}$, reaching values as high as the SRO-Fe pool (Figure S8). In the latter case (higher $\mathrm{Fe}^{\mathrm{III}}{ }_{\mathrm{RR}}$ ), we would expect a soil primed for rapid and sustained $\mathrm{Fe} \mathrm{e}^{\mathrm{III}}$ reduction, while in the former, the length of Fe reduction might be much lower (lower $\mathrm{Fe}^{\mathrm{III}}{ }_{\mathrm{RR}}$ ). Given the emerging understanding that $\mathrm{Fe}^{\mathrm{IIII}}$ reduction is a critical electron-accepting process that is responsible for carbon mineralization in humid forest soils, the abundance of $\mathrm{Fe}^{\mathrm{III}}$ RR may be an important control of C-cycling.

\subsection{Soil Moisture and Precipitation Influence Fe-C Redox Cycling}

Soil moisture was a predictor for the Media- $\mathrm{Fe}_{\mathrm{RR}}^{\mathrm{III}}$, Shewa-Fe ${ }_{\mathrm{RR}}^{\mathrm{III}}, \mathrm{DOC}$, and $\mathrm{F}\left(\mathrm{CO}_{2}\right)$ models. Additionally, soil moisture influenced the $\mathrm{Fe}^{\mathrm{III}}{ }_{\mathrm{RR}}$ pool, and consequently influenced $\mathrm{Fe}^{\mathrm{II}}$ concentrations. 
Precipitation was a predictor for the environmental factors $E h, \mathrm{O}_{2}$, and $\theta_{\mathrm{V}}$, which are important parameters that influence $\mathrm{Fe}-\mathrm{C}$ reduction and oxidation (Figures 2 and 3). Prior work has shown that precipitation was inversely correlated with soil $\mathrm{O}_{2}$ concentrations across the LEF [11]. By evaluating the relationship between precipitation and $\mathrm{O}_{2}$, Liptzin, Silver and Detto [37] found that dry periods of at least four days were able to aerate soils, while a small rainfall event $(<1 \mathrm{~mm})$ was able to create low $\mathrm{O}_{2}$ concentrations. We first hypothesized that precipitation would be a strong predictor for most of the soil biogeochemical variables. However, unlike soil moisture, precipitation did not prevail in the stepwise backward elimination models for $\mathrm{Fe}^{\mathrm{II}}, \mathrm{Media}^{\mathrm{F}} \mathrm{F}^{\mathrm{III}}{ }_{\mathrm{RR}}$, Shewa-Fe ${ }^{\mathrm{III}}{ }_{\mathrm{RR}}, \mathrm{DOC}$, $\mathrm{F}\left(\mathrm{CO}_{2}\right)$, and $\mathrm{F}\left(\mathrm{CH}_{4}\right)$. This suggests that rainfall does not have an immediate impact on $\mathrm{Fe}$ and $\mathrm{C}$ biogeochemistry, but rather it is the accumulation of water in the soil (soil moisture) that has a rapid impact on these parameters; reinforcing that soil moisture drives biogeochemical cycling, not rainfall. Additionally, elevated soil moisture content had a strong relationship with the potential for Fe reduction as measured by uniformly oxidized steel rods (i.e., Indicator of Reduction in Soils-IRIS) deployed across a topographic gradient in volcanic soils from Hawaii [76], and also in upland Fe-rich and weathered soils from the United States (USA) southeastern piedmont [77]. In these studies, Fe reduction was likely stimulated by exogenous $\mathrm{C}$ inputs (such as DOC). Therefore, the temporal and spatial variation in soil moisture, $\mathrm{O}_{2}$ content, and redox conditions may create a hot moment for $\mathrm{Fe}$ reduction in soils within certain hot spots of the landscape $[4,40]$.

In soils that undergo redox fluctuations, $\mathrm{C}$ has been shown to both accumulate in the form of solid phase $C$ or be lost via solubilization or mineralization by soil microorganisms $[78,79]$. In our study, DOC was positively correlated to $\mathrm{Fe}^{\mathrm{II}}$ and $\theta_{\mathrm{G}}$, suggesting that the release of DOC is likely driven by the desorption/dissolution of organic matter from reactive $\mathrm{Fe}^{\mathrm{III}}$ phases that undergo reductive dissolution [80]. Consequently, DOC concentrations depend on the resident Fe reduction processes (as $\mathrm{Fe}^{\mathrm{II}}$ is a predictive variable in the model for DOC) and on the soil moisture conditions. Our results corroborate prior work reporting that variations in DOC are correlated with changes in dissolved ferrous iron $\left(\mathrm{Fe}^{\mathrm{II}}\right)[28,29]$. During anoxic incubations of wetland soils, Grybos, et al. [81] observed that DOC increases were correlated with increases in $\mathrm{pH}$ as well as in $\mathrm{Fe}^{\mathrm{II}}$ and $\mathrm{Mn}^{\mathrm{II}}$ concentrations, and with decreases in Eh. These soluble $\mathrm{C}$ forms can be depolymerized and/or mineralized to $\mathrm{CO}_{2}$ and $\mathrm{CH}_{4}$ emissions by microbial activity [82]. In our models, we found that soil moisture was a predictor for $\mathrm{F}\left(\mathrm{CO}_{2}\right)$ and soil $\mathrm{pH}$ predictor for $\mathrm{F}\left(\mathrm{CH}_{4}\right)$; and, interestingly, we found no relationship between $\mathrm{F}\left(\mathrm{CO}_{2}\right)$ and $\mathrm{F}\left(\mathrm{CH}_{4}\right)$ with the iron pools $\mathrm{Fe}^{\mathrm{II}}$ and $\mathrm{Fe}^{\mathrm{III}}{ }_{\mathrm{RR}}$. Similar to our models, other studies demonstrated that $\mathrm{F}\left(\mathrm{CO}_{2}\right)$ decreased with increasing soil moisture content [83-85], and that $\mathrm{F}\left(\mathrm{CH}_{4}\right)$ increased with increasing soil pH (between 4.5 to 6.5, Figure S7), for example, in inundated systems [86].

The decline in precipitation and soil moisture in the last 12 days of the field campaign correlated with a decrease in $\mathrm{Fe}^{\mathrm{II}}, \mathrm{Fe}^{\mathrm{III}} \mathrm{RR}_{2}, \mathrm{DOC}$, and an increase in $\mathrm{Eh}$ and $\mathrm{O}_{2}$ values at most of the sites. The decrease in both $\mathrm{Fe}^{\mathrm{II}}$ and $\mathrm{DOC}$ concentrations could be due to the potential disappearance of anoxic microsites within the soils as the soil dried and $\mathrm{O}_{2}$ content increased [4]. Thus, decreasing soil moisture conditions appeared to directly impact the dynamics of $\mathrm{Fe}$ and $\mathrm{C}$ with important ecosystem implications.

\section{Conclusions}

We found that variation in precipitation, soil moisture, and $\mathrm{O}_{2}$ content impacted the pools of Fe and $\mathrm{C}$ extracted from soils across different landscape positions and influenced fluctuations in soil redox potential. The pool of reactive and rapidly reducible $\mathrm{Fe}$ oxides $\left(\mathrm{Fe}^{\mathrm{III}} \mathrm{RR}_{\mathrm{R}}\right)$ was dynamic and depended on fluctuating environmental conditions. We also found that the characteristic turnover time for $\mathrm{HCl}$-extractable $\mathrm{Fe}^{\mathrm{II}}$ (calculated based on both production and consumption) was four days. In conclusion, intensive periods of precipitation and prolonged dry periods were able to create distinct hot moments for biogeochemical redox processes. We found that valleys generally behaved as environmental hot spots within the landscape. 
Robust relationships between soil moisture and the variables Media-Fe ${ }_{\text {RR, }}^{\mathrm{III}}$, Shewa-Fe ${ }_{\text {III }}{ }_{R R}, \mathrm{DOC}$, and $\mathrm{CO}_{2}$ demonstrate the strong influence of soil water content on these biogeochemical processes. Both Media- $\mathrm{Fe}^{\mathrm{III}} \mathrm{RR}$ and Shewa-Fe ${ }^{\mathrm{III}}$ RR were correlated to $\mathrm{Fe}^{\mathrm{II}}$ concentrations in the studied soils. Thus, large amounts of precipitation or the occurrence of drier periods could likely further constrain these biogeochemical processes. We demonstrated that precipitation and the environmental factors of soil moisture and $\mathrm{O}_{2}$ content are interconnected and important predictors for Fe reduction, DOC release, $\mathrm{C}$ mineralization, and fluctuations in soil redox potential, with important ecosystem implications over variant topographic positions in highly weathered Fe-rich soils from humid tropical regions.

Supplementary Materials: The following are available online at http://www.mdpi.com/2571-8789/2/4/59/s1, Figure S1: Illustration of sampling design at one of the catenas: (a) showing ridge, slope, and valley topographic positions, the 3 plots allocated within each site, the sensors distributed within the plots, and (b) example of a subplot of $1.5 \mathrm{~m} \times 1.5 \mathrm{~m}$, sampled at $0-15 \mathrm{~cm}$ depth with sampling points randomly located at least $20 \mathrm{~cm}$ apart. Luquillo CZO, Puerto Rico (2016), Figure S2: Visualization of subplots Catena-2: (a) slope, (b) ridge, and (c) valley; and (d) valley in Catena-3. Luquillo CZO, Puerto Rico (2016), Figure S3: Principal Component Analysis (PCA) for the 9 sites, valleys (V1, V2, V3), slopes (S1, S2, and S3), and ridges (R1, R2, R3) based on the following soil characteristics: Total-Fe, SRO-Fe, Total-C, Sand, Silt, and Clay content. Soils from Luquillo CZO, Puerto Rico, sampled in 2016, Figure S4: Soil pH (1:1 soil:water). Soils from Luquillo CZO, Puerto Rico, Figure S5: Gravimetric Water Content. Soils from Luquillo CZO, Puerto Rico, Figure S6. Soil CO2 and CH4 emissions. Soils from Luquillo $\mathrm{CZO}$, Puerto Rico, Figure S7: Values for $\mathrm{pH}$ and $\mathrm{CH}_{4}$ fluxes (a) with and (b) without the outliers, Figure S8: Pools of Total-Fe, SRO-Fe, $\mathrm{Fe}^{\mathrm{III}}{ }_{\mathrm{RR}}$, and $\mathrm{Fe}^{\mathrm{II}}$ for two given sampling days (left and right) for valley-1. The pool of $\mathrm{Fe}^{\mathrm{III}}{ }_{\mathrm{RR}}$ is dynamic and can be as high as the SRO-Fe pool. Soils from Luquillo CZO, Puerto Rico, sampled in 2016, Table S1: GPS coordinates of the studied site, Table S2: Total elemental analysis (concentrations in \%). Soils from Luquillo CZO, Puerto Rico, sampled in 2016, Table S3: Turnover Times for HCl-extractable Fe ${ }^{\mathrm{II}}$ Production and $\mathrm{HCl}$-extractable $\mathrm{Fe}^{\mathrm{II}}$ Consumption: highest frequency, median and mean, Table S4: Parameters used for each variable studied before stepwise backward elimination, Table S5: Number of hours before soil sampling the environmental factors are averaged that yielded the lowest AIC (best model). It represents the best averaging window to predict each variable in the mixed linear models (from 1 to $48 \mathrm{~h}$ of soil sampling), Table S6. Comparison of reactive iron pool (SRO-Fe) extracted by Citrate-Ascorbate and the Fe reduced within 7 days by incubations with Shewa-Fe ${ }_{R R}^{\mathrm{III}}$ and Media-Fe ${ }_{\text {III }}$ : (a) for the actual values in $\mathrm{mmol} \mathrm{kg}^{-1}$ for the 7 day-incubation, and (b) for ratio between $\mathrm{Fe}^{\mathrm{III}} \mathrm{RR}$ pool and the SRO-Fe pool (in percent).

Author Contributions: Conceptualization, D.B., C.S.O., W.S., A.T.; investigation, D.B., C.S.O., W.S., A.T., formal analysis, D.B., C.S.O., C.M., A.T.; data curation, D.B., C.M., A.T.; software, C.M.; funding acquisition, W.S., A.T.; supervision, A.T.; writing-review and editing, D.B., C.S.O., W.S., C.M., A.T.

Funding: Funding for this research was provided by National Science Foundation (NSF), grants EAR-1331841 and DEB-1457761.

Acknowledgments: We thank all members of the Thompson Lab (especially Nehru Mantripragada) for technical assistance. Thanks to the El Verde Research Station personal for providing support to this research (especially Francisco Perez), and to the Critical Zone Observatories Network.

Conflicts of Interest: The authors declare no conflict of interest.

\section{References}

1. Kleber, M.; Eusterhues, K.; Keiluweit, M.; Mikutta, C.; Mikutta, R.; Nico, P.S. Mineral-organic associations: Formation, properties, and relevance in soil environments. Adv. Agron. 2015, 130, 1-140.

2. FAO. Status of the World's Soil Resources (SWSR)-Main Report. In Food and Agriculture Organization of the United Nations and Intergovernmental Technical Panel on Soils; FAO: Rome, Italy, 2015; Volume 650.

3. Broedel, E.; Tomasella, J.; Cândido, L.A.; Randow, C. Deep soil water dynamics in an undisturbed primary forest in central Amazonia: Differences between normal years and the 2005 drought. Hydrol. Process. 2017, 31, 1749-1759. [CrossRef]

4. Hall, S.J.; McDowell, W.H.; Silver, W.L. When wet gets wetter: Decoupling of moisture, redox biogeochemistry, and greenhouse gas fluxes in a humid tropical forest soil. Ecosystems 2013, 16, 576-589. [CrossRef]

5. $\quad$ Saleska, S.R.; Miller, S.D.; Matross, D.M.; Goulden, M.L.; Wofsy, S.C.; Da Rocha, H.R.; De Camargo, P.B.; Crill, P.; Daube, B.C.; De Freitas, H.C. Carbon in Amazon forests: Unexpected seasonal fluxes and disturbance-induced losses. Science 2003, 302, 1554-1557. [CrossRef] [PubMed] 
6. Álvarez-Dávila, E.; Cayuela, L.; González-Caro, S.; Aldana, A.M.; Stevenson, P.R.; Phillips, O.; Cogollo, Á.; Peñuela, M.C.; von Hildebrand, P.; Jiménez, E. Forest biomass density across large climate gradients in northern South America is related to water availability but not with temperature. PLoS ONE 2017, 12, e0171072. [CrossRef] [PubMed]

7. Brokaw, N.; Crowl, T.A.; Lugo, A.; McDowell, W.H.; Scatena, F.; Waide, R.B.; Willig, M.R. A Caribbean Forest Tapestry: The Multidimensional Nature of Disturbance and Response; Oxford University Press: New York, NY, USA, 2012.

8. Muggler, C.C.; van Griethuysen, C.; Buurman, P.; Pape, T. Aggregation, organic matter, and iron oxide morphology in Oxisols from Minas Gerais, Brazil. Soil Sci. 1999, 164, 759-770. [CrossRef]

9. Rezende, M.; Curi, N.; Rezende, S.; Corrêa, G. Pedologia: Base Para Distinção de Ambientes, 5th ed.; Editora UFLA: Lavras, Brazil, 2007; p. 322.

10. Cleveland, C. Nitrogen and phosphorus additions cause substantial losses of soil carbon from a lowland tropical rain forest. Proc. Natl. Acad. Sci. USA 2006, 103, 10316-10321. [CrossRef] [PubMed]

11. Silver, W.L.; Lugo, A.; Keller, M. Soil oxygen availability and biogeochemistry along rainfall and topographic gradients in upland wet tropical forest soils. Biogeochemistry 1999, 44, 301-328. [CrossRef]

12. Martin, S.T. Precipitation and dissolution of iron and manganese oxides. In Environmental Catalysis; CRC Press: Boca Raton, FL, USA, 2005; pp. 61-81.

13. Peters, V.; Conrad, R. Sequential reduction processes and initiation of $\mathrm{CH} 4$ production upon flooding of oxic upland soils. Soil Biol. Biochem. 1996, 28, 371-382. [CrossRef]

14. Hall, S.J.; Huang, W. Iron reduction: A mechanism for dynamic cycling of occluded cations in tropical forest soils? Biogeochemistry 2017, 136, 91-102. [CrossRef]

15. Lovley, D.R. Fe (III) and Mn (IV) reduction. In Environmental Microbe-Metal Interactions; American Society of Microbiology: Washington, DC, USA, 2000; pp. 3-30.

16. Mikutta, R.; Kleber, M.; Torn, M.S.; Jahn, R. Stabilization of soil organic matter: Association with minerals or chemical recalcitrance? Biogeochemistry 2006, 77, 25-56. [CrossRef]

17. Lugo, A.E.; Brown, S.; Brinson, M.M. Concepts in wetland ecology. Ecosyst. World 1990, 15, 53-85.

18. Ginn, B.; Meile, C.; Wilmoth, J.; Tang, Y.; Thompson, A. Rapid Iron Reduction Rates Are Stimulated by High-Amplitude Redox Fluctuations in a Tropical Forest Soil. Environ. Sci. Technol. 2017, 51, 3250-3259. [CrossRef]

19. Weber, K.A.; Achenbach, L.A.; Coates, J.D. Microorganisms pumping iron: Anaerobic microbial iron oxidation and reduction. Nat. Rev. Microbiol. 2006, 4, 752-764.

20. Cornell, R.M.; Schwertmann, U. The Iron Oxides: Structure, Properties, Reactions, Occurrences and Uses; Wiley-VCH: Weinheim, Germany, 2003; p. 667.

21. Neff, J.C.; Asner, G.P. Dissolved organic carbon in terrestrial ecosystems: Synthesis and a model. Ecosystems 2001, 4, 29-48. [CrossRef]

22. Gottschalk, P.; Smith, J.U.; Wattenbach, M.; Bellarby, J.; Stehfest, E.; Arnell, N.; Osborn, T.; Jones, C.; Smith, P. How will organic carbon stocks in mineral soils evolve under future climate? Global projections using RothC for a range of climate change scenarios. Biogeosciences 2012, 9, 3151. [CrossRef]

23. Lovley, D.R.; Holmes, D.E.; Nevin, K.P. Dissimilatory fe (iii) and mn (iv) reduction. Adv. Microb. Physiol. 2004, 49, 219-286. [PubMed]

24. Carmo, J.B.D.; Keller, M.; Dias, J.D.; Camargo, P.B.D.; Crill, P. A source of methane from upland forests in the Brazilian Amazon. Geophys. Res. Lett. 2006, 33. [CrossRef]

25. Rasmussen, C.; Throckmorton, H.; Liles, G.; Heckman, K.; Meding, S.; Horwath, W. Controls on Soil Organic Carbon Partitioning and Stabilization in the California Sierra Nevada. Soil Syst. 2018, 2, 41.

26. Huang, W.; Hall, S.J. Elevated moisture stimulates carbon loss from mineral soils by releasing protected organic matter. Nat. Commun. 2017, 8, 1774.

27. Hall, S.J.; Silver, W.L. Iron oxidation stimulates organic matter decomposition in humid tropical forest soils. Glob. Chang. Biol. 2013, 19, 2804-2813. [CrossRef] [PubMed]

28. Knorr, K.-H. DOC-dynamics in a small headwater catchment as driven by redox fluctuations and hydrological flow paths-are DOC exports mediated by iron reduction/oxidation cycles? Biogeosciences 2013, 10, 891. [CrossRef]

29. Blodau, C.; Fulda, B.; Bauer, M.; Knorr, K.-H. Arsenic speciation and turnover in intact organic soil mesocosms during experimental drought and rewetting. Geochim. Cosmochim. Acta 2008, 72, 3991-4007. [CrossRef] 
30. Chen, C.; Thompson, A. Ferrous Iron Oxidation under Varying pO2 Levels: The Effect of Fe (III)/ Al (III) Oxide Minerals and Organic Matter. Environ. Sci. Technol. 2018, 52, 597-606. [CrossRef] [PubMed]

31. Thaymuang, W.; Kheoruenromne, I.; Suddhipraharn, A.; Sparks, D.L. The role of mineralogy in organic matter stabilization in tropical soils. Soil Sci. 2013, 178, 308-315. [CrossRef]

32. Souza, I.F.; Almeida, L.F.; Jesus, G.L.; Pett-Ridge, J.; Nico, P.S.; Kleber, M.; Silva, I.R. Carbon Sink Strength of Subsurface Horizons in Brazilian Oxisols. Soil Sci. Soc. Am. J. 2018, 82, 76-86. [CrossRef]

33. Silva, L.C.; Doane, T.A.; Corrêa, R.S.; Valverde, V.; Pereira, E.I.; Horwath, W.R. Iron-mediated stabilization of soil carbon amplifies the benefits of ecological restoration in degraded lands. Ecol. Appl. 2015, 25, 1226-1234. [CrossRef] [PubMed]

34. Silva Neto, L.F.; Vasconcellos Inda, A.; Bayer, C.; Pinheiro Dick, D.; Tiago Tonin, A. Óxidos de ferro em latossolos tropicais e subtropicais brasileiros em plantio direto. Rev. Bras. Ciênc. Solo 2008, 32, 1873-1881. [CrossRef]

35. Hall, S.J.; Silver, W.L. Reducing conditions, reactive metals, and their interactions can explain spatial patterns of surface soil carbon in a humid tropical forest. Biogeochemistry 2015, 125, 149-165. [CrossRef]

36. O'Connell, C.S.; Ruan, L.; Silver, W.L. Drought drives rapid shifts in tropical rainforest soil biogeochemistry and greenhouse gas emissions. Nat. Commun. 2018, 9, 1348. [CrossRef] [PubMed]

37. Liptzin, D.; Silver, W.L.; Detto, M. Temporal Dynamics in Soil Oxygen and Greenhouse Gases in Two Humid Tropical Forests. Ecosystems 2011, 14, 171-182. [CrossRef]

38. Hook, P.B.; Burke, I.C. Biogeochemistry in a shortgrass landscape: Control by topography, soil texture, and microclimate. Ecology 2000, 81, 2686-2703.

39. Bernhardt, E.S.; Blaszczak, J.R.; Ficken, C.D.; Fork, M.L.; Kaiser, K.E.; Seybold, E.C. Control points in ecosystems: Moving beyond the hot spot hot moment concept. Ecosystems 2017, 20, 665-682. [CrossRef]

40. McClain, M.E.; Boyer, E.W.; Dent, C.L.; Gergel, S.E.; Grimm, N.B.; Groffman, P.M.; Hart, S.C.; Harvey, J.W.; Johnston, C.A.; Mayorga, E. Biogeochemical hot spots and hot moments at the interface of terrestrial and aquatic ecosystems. Ecosystems 2003, 6, 301-312. [CrossRef]

41. Vargas, R.; Sánchez-Cañete, P.E.; Serrano-Ortiz, P.; Curiel Yuste, J.; Domingo, F.; López-Ballesteros, A.; Oyonarte, C. Hot-Moments of Soil $\mathrm{CO}_{2}$ Efflux in a Water-Limited Grassland. Soil Syst. 2018, 2, 47. [CrossRef]

42. Seiders, V.M. Cretaceous and Lower Tertiary Stratigraphy of the Gurabo and El Yunque Quadrangles, Puerto Rico. 1971. Available online: http:/ / agris.fao.org/agris-search/search.do?recordID=US201300472921 (accessed on 14 June 2017).

43. Hodge, E.T. Geology of the Coamo-Guayama District; New York Academy of Sciences: New York, NY, USA, 1920; Volume 28.

44. Heartsill-Scalley, T.; Scatena, F.N.; Estrada, C.; McDowell, W.; Lugo, A.E. Disturbance and long-term patterns of rainfall and throughfall nutrient fluxes in a subtropical wet forest in Puerto Rico. J. Hydrol. 2007, 333, 472-485. [CrossRef]

45. Scatena, F.N. An Introduction to the Physiography and History of the Bisley Experimental Watersheds in the Luquillo Mountains of Puerto Rico; Gen. Tech. Report SO-72; US Department of Agriculture, Forest Service, Southern Forest Experiment Station: New Orleans, LA, USA, 1989; Volume 72.

46. Almaraz, M. Nitrogen Availability and Loss from Unmanaged and Managed Ecosystems. Ph.D. Thesis, Brown University, Providence, RI, USA, 2017.

47. McDowell, W.; Estrada-Pinto, A. Rainfall at the El Verde Field Station, 1964-1986; CEER T-228; University of Puerto Rico: San Juan, Puerto Rico, 1988.

48. Ginn, B.R.; Habteselassie, M.Y.; Meile, C.; Thompson, A. Effects of sample storage on microbial Fe-reduction in tropical rainforest soils. Soil Biol. Biochem. 2014, 68, 44-51. [CrossRef]

49. Barcellos, D.; Cyle, K.T.; Thompson, A. Faster redox fluctuations can lead to higher iron reduction rates in humid forest soils. Biogeochemistry 2018, 137, 367-378. [CrossRef]

50. Thompson, A.; Chadwick, O.A.; Rancourt, D.G.; Chorover, J. Iron-oxide crystallinity increases during soil redox oscillations. Geochim. Cosmochim. Acta 2006, 70, 1710-1727. [CrossRef]

51. Huang, W.; Hall, S.J. Optimized high-throughput methods for quantifying iron biogeochemical dynamics in soil. Geoderma 2017, 306, 67-72. [CrossRef]

52. Haynes, R.; Francis, G. Changes in microbial biomass C, soil carbohydrate composition and aggregate stability induced by growth of selected crop and forage species under field conditions. Eur. J. Soil Sci. 1993, 44, 665-675. [CrossRef] 
53. Boyer, J.; Groffman, P. Bioavailability of water extractable organic carbon fractions in forest and agricultural soil profiles. Soil Biol. Biochem. 1996, 28, 783-790. [CrossRef]

54. Ghani, A.; Dexter, M.; Perrott, K. Hot-water extractable carbon in soils: A sensitive measurement for determining impacts of fertilisation, grazing and cultivation. Soil Biol. Biochem. 2003, 35, 1231-1243. [CrossRef]

55. Guigue, J.; Mathieu, O.; Lévêque, J.; Mounier, S.; Laffont, R.; Maron, P.-A.; Navarro, N.; Chateau, C.; Amiotte-Suchet, P.; Lucas, Y. A comparison of extraction procedures for water-extractable organic matter in soils. Eur. J. Soil Sci. 2014, 65, 520-530. [CrossRef]

56. Pachon, J.C.; Kowalski, K.; Butterick, J.; Bacon, A.R. The quantified effect of real refractive index assumptions on laser diffraction mechanical analysis. Soil Sci. Soc. Am. J. 2018, in press.

57. Bonneville, S.; Van Cappellen, P.; Behrends, T. Microbial reduction of iron (III) oxyhydroxides: Effects of mineral solubility and availability. Chem. Geol. 2004, 212, 255-268. [CrossRef]

58. Bonneville, S.; Behrends, T.; Van Cappellen, P. Solubility and dissimilatory reduction kinetics of iron (III) oxyhydroxides: A linear free energy relationship. Geochim. Cosmochim. Acta 2009, 73, 5273-5282. [CrossRef]

59. Eusterhues, K.; Hädrich, A.; Neidhardt, J.; Küsel, K.; Keller, T.; Jandt, K.; Totsche, K. Reduction of ferrihydrite with adsorbed and coprecipitated organic matter: Microbial reduction by Geobacter bremensis vs. abiotic reduction by Na-dithionite. Biogeosciences 2014, 11, 4953. [CrossRef]

60. Fiedler, S.; Vepraskas, M.J.; Richardson, J. Soil redox potential: Importance, field measurements, and observations. Adv. Agron. 2007, 94, 1-54.

61. Husson, O. Redox potential (Eh) and $\mathrm{pH}$ as drivers of soil/plant/microorganism systems: A transdisciplinary overview pointing to integrative opportunities for agronomy. Plant Soil 2013, 362, 389-417. [CrossRef]

62. Patrick, W.; Gambrell, R.; Faulkner, S. Redox measurements of soils. In Methods of Soil Analysis Part 3-Chemical Methods; Soil Science Society of America: Madison, WI, USA, 1996; pp. 1255-1273.

63. Sparks, D.L. Environmental Soil Chemistry; Academic Press: San Diego, CA, USA, 2003; p. 351.

64. Bates, D.; Mächler, M.; Bolker, B.; Walker, S. Fitting linear mixed-effects models using lme4. arXiv 2014.

65. Johnson, P.C. Extension of Nakagawa \& Schielzeth's R2GLMM to random slopes models. Methods Ecol. Evol. 2014, 5, 944-946. [PubMed]

66. Nakagawa, S.; Schielzeth, H. A general and simple method for obtaining R2 from generalized linear mixed-effects models. Methods Ecol. Evol. 2013, 4, 133-142. [CrossRef]

67. Ponnamperuma, F.N. The chemistry of submerged soils. Adv. Agron. 1972, 24, $29-96$.

68. Barcellos, D. Biogeochemical Cycling of Iron and Carbon in Humid (Sub)tropical Forest Soils under Fluctuating Redox Conditions. Ph.D. Thesis, University of Georgia, Athens, GA, USA, 2018.

69. Wang, Y.; Van Cappellen, P. A multicomponent reactive transport model of early diagenesis: Application to redox cycling in coastal marine sediments. Geochim. Cosmochim. Acta 1996, 60, 2993-3014. [CrossRef]

70. Berg, P.; Rysgaard, S.; Thamdrup, B. Dynamic modeling of early diagenesis and nutrient cycling. A case study in an artic marine sediment. Am. J. Sci. 2003, 303, 905-955. [CrossRef]

71. Boudreau, B.P. A method-of-lines code for carbon and nutrient diagenesis in aquatic sediments. Comput. Geosci. 1996, 22, 479-496. [CrossRef]

72. Hall, S.J.; Liptzin, D.; Buss, H.L.; DeAngelis, K.; Silver, W.L. Drivers and patterns of iron redox cycling from surface to bedrock in a deep tropical forest soil: A new conceptual model. Biogeochemistry 2016, 130, 177-190. [CrossRef]

73. Chen, C.; Meile, C.; Wilmoth, J.; Barcellos, D.; Thompson, A. Influence of $\mathrm{PO}_{2}$ on Iron Redox Cycling and Anaerobic Organic Carbon Mineralization in a Humid Tropical Forest Soil. Environ. Sci. Technol. 2018, 52, 7709-7719. [CrossRef] [PubMed]

74. Wilmoth, J.L.; Moran, M.A.; Thompson, A. Transient $\mathrm{O}_{2}$ pulses direct Fe crystallinity and Fe(III)-reducer gene expression within a soil microbiome. Microbiome 2018, 6, 189. [CrossRef] [PubMed]

75. Coward, E.K.; Thompson, A.T.; Plante, A.F. Iron-mediated mineralogical control of organic matter accumulation in tropical soils. Geoderma 2017, 306, 206-216. [CrossRef]

76. Hodges, C.; King, E.; Pett-Ridge, J.; Thompson, A. Potential for Iron Reduction Increases with Rainfall in Montane Basaltic Soils of Hawaii. Soil Sci. Soc. Am. J. 2018, 82, 176-185. [CrossRef]

77. Hodges, C.A. Drivers and Variability of Iron Reduction in Upland Soils. Master's Thesis, University of Georgia, Athens, GA, USA, 2017. 
78. Kögel-Knabner, I. The macromolecular organic composition of plant and microbial residues as inputs to soil organic matter: Fourteen years on. Soil Biol. Biochem. 2017, 105, A3-A8. [CrossRef]

79. Six, J.; Conant, R.; Paul, E.; Paustian, K. Stabilization mechanisms of soil organic matter: Implications for C-saturation of soils. Plant Soil 2002, 241, 155-176. [CrossRef]

80. Buettner, S.W.; Kramer, M.G.; Chadwick, O.A.; Thompson, A. Mobilization of colloidal carbon during iron reduction in basaltic soils. Geoderma 2014, 221, 139-145. [CrossRef]

81. Grybos, M.; Davranche, M.; Gruau, G.; Petitjean, P.; Pédrot, M. Increasing pH drives organic matter solubilization from wetland soils under reducing conditions. Geoderma 2009, 154, 13-19. [CrossRef]

82. Keiluweit, M.; Nico, P.S.; Kleber, M.; Fendorf, S. Are oxygen limitations under recognized regulators of organic carbon turnover in upland soils? Biogeochemistry 2016, 127, 157-171. [CrossRef]

83. Manabe, S.; Wetherald, R.T. Reduction in summer soil wetness induced by an increase in atmospheric carbon dioxide. Science 1986, 232, 626-628. [CrossRef] [PubMed]

84. Davidson, E.A.; Belk, E.; Boone, R.D. Soil water content and temperature as independent or confounded factors controlling soil respiration in a temperate mixed hardwood forest. Glob. Chang. Biol. 1998, 4, $217-227$. [CrossRef]

85. $\mathrm{Xu}, \mathrm{M}$; $\mathrm{Qi}$, Y. Soil-surface $\mathrm{CO}_{2}$ efflux and its spatial and temporal variations in a young ponderosa pine plantation in northern California. Glob. Chang. Biol. 2001, 7, 667-677. [CrossRef]

86. Wang, Z.; Delaune, R.; Patrick, W.; Masscheleyn, P. Soil redox and $\mathrm{pH}$ effects on methane production in a flooded rice soil. Soil Sci. Soc. Am. J. 1993, 57, 382-385. [CrossRef]

(C) 2018 by the authors. Licensee MDPI, Basel, Switzerland. This article is an open access article distributed under the terms and conditions of the Creative Commons Attribution (CC BY) license (http://creativecommons.org/licenses/by/4.0/). 